\title{
Improving herpetological surveys in eastern North America using the environmental DNA method
}

\begin{tabular}{|r|l|}
\hline Journal: & Genome \\
\hline Manuscript ID & gen-2015-0218.R3 \\
\hline Manuscript Type: & Article \\
\hline Date Submitted by the Author: & 02-Aug-2016 \\
\hline Complete List of Authors: & $\begin{array}{l}\text { Lacoursière-Roussel, Anaïs; Université Laval, Biology } \\
\text { Dubois, Yohann; Ministère des Forêts, de la Faune et des Parcs, Direction } \\
\text { de I'expertise sur la faune terrestre, I'herpétofaune et l'avifaune } \\
\text { Normandeau, Eric; Université Laval, Biology } \\
\text { Bernatchez, Louis; Université Laval, Biology }\end{array}$ \\
\hline Keyword: & amphibian, reptile, monitoring, qPCR, eDNA metabarcoding \\
\hline & \\
\hline
\end{tabular}




\title{
Improving herpetological surveys in eastern North America using the environmental DNA method
}

\author{
Genome Special Edition
}

Anaïs Lacoursière-Roussel ${ }^{1}$, Yohann Dubois ${ }^{2}$, Eric Normandeau $^{1}$ and Louis Bernatchez ${ }^{1}$

Correspondence author: Anaïs Lacoursière-Roussel, anais.lacoursiere.1@ulaval.ca, Telephone: (+1) 418-932-0700, Fax: (+1) 418-656-7176

${ }^{1}$ Institut de Biologie Intégrative et des Systèmes (IBIS), Pavillon Charles Eugène Marchand, Université Laval, Québec (Québec), Canada, G1V 0A6

${ }^{2}$ Ministère des Forêts, de la Faune et des Parcs, Direction de l'expertise sur la faune terrestre, l'herpétofaune et l'avifaune, 880 chemin Sainte-Foy, Québec (Québec), G1S $4 \mathrm{X} 4$

Running title: Improving herpetological surveys using the eDNA 


\begin{abstract}
Among vertebrates, herpetofauna has the highest proportion of declining species. Detection of eDNA is a promising method towards significantly increasing large-scale herpetological conservation efforts. However, the integration of eDNA results within a management framework requires an evaluation of the efficiency of the method in large natural environments and the calibration of eDNA surveys with the quantitative monitoring tools currently used by conservation biologists. Towards this end, we first developed species-specific primers to detect the Wood turtle (Glyptemys insculpta) a species at risk in Canada, by quantitative PCR (qPCR). The rate of eDNA detection obtained by qPCR was also compared to the relative abundance of this species in nine rivers obtained by standardized visual surveys in the Province of Québec (Canada). Secondly, we developed multi-species primers to detect North American amphibian and reptile species using eDNA metabarcoding analysis. An occurrence index based on the distribution range and habitat type was compared with the eDNA metabarcoding dataset from samples collected in seven lakes and five rivers. Our results empirically support the effectiveness of eDNA metabarcoding to characterize herpetological species distributions. Moreover, detection rates provided similar results to standardized visual surveys currently used to develop conservation strategies for the Wood turtle. We conclude that eDNA detection rates may provide an effective semi-quantitative survey tool, provided that assay calibration and standardization is performed.
\end{abstract}

Keywords: amphibian, reptile, monitoring, eDNA metabarcoding, qPCR. 


\section{INTRODUCTION}

Herpetofauna, including the amphibians and reptiles, faces the highest proportion of declining species among the vertebrates (Alroy 2015; Böhm et al. 2013; Gibbons et al. 2000; Houlahan et al. 2000; IUCN 2016; Stuart et al. 2004). However, the lack of data on species distribution and population demographic trends currently limits the development of effective conservation strategies (Baillie et al. 2010; Howard and Bickford 2014; Stuart et al. 2004). Effective non-invasive monitoring tools are needed to properly assess the status of species, to locate populations for conservation efforts, and to describe population trends in relation to threats intensities and possible recovery actions (Campbell et al. 2002). Due to their ecology and life history traits, many amphibians and reptiles are very difficult to detect using classical monitoring methods (Bailey et al. 2004a; Couturier et al. 2013; Daigle and Jutras 2005; Lind et al. 2005; Price et al. 2012). To increase detection probability with practical efforts, surveys and monitoring programs are generally limited to a time window maximizing species detection (Erb et al. 2015; Massachusetts Cooperative Fish and Wildlife Research Unit and the Northeast Wood Turtle Working Group 2013; Petitot et al. 2014). Additionally, the time window optimizing species detection differs from one species to another, therefore limiting the ability of developing simultaneous monitoring programs for the different species (Bailey et al. 2004b; de Solla et al. 2005; Pellet and Schmidt 2005). Improving distribution data for every species or for the entire range of a species within a jurisdiction territory using non-invasive methods is thus particularly challenging for large-scale herpetological management purposes. 
Analysis of environmental DNA (eDNA) is likely to become a revolutionary tool to increase both spatial and temporal scales of monitoring datasets for species of concern (Dejean et al. 2012; Jerde et al. 2013; Jerde et al. 2011; Lodge et al. 2012; Mahon et al. 2013; Pilliod et al. 2013a; Thomsen et al. 2012a). The eDNA method detects traces of DNA in cellular or extracellular form from sources such as feces, secreted mucous membranes, gametes and skin cells (Haile et al. 2009; Lydolph et al. 2005; Taberlet et al. 2012). In addition to increasing the probability of detection of aquatic species compared to some traditional survey methods (Dejean et al. 2012; Jerde et al. 2011; Pilliod et al. 2013a; Smart et al. 2015), using eDNA might also increase the observation time windows for surveys, enabling multispecies surveys and reducing the need for extensive taxonomic expertise and financial resources.

The successful detection of American bullfrogs (Lithobates catesbeianus) eDNA in natural ponds in 2008 (Ficetola et al. 2008) led amphibians to become model organisms for eDNA research (Thomsen and Willerslev 2015; Valentini et al. 2015). Recently, Davy et al. (2015) showed that eDNA could also be used to detect reptiles, namely freshwater turtles, in outdoor ponds. However, for both reptiles and amphibians, few studies have evaluated the efficiency of the eDNA method in large natural aquatic environments such as lakes and rivers, as well as the relative sensitivity of the method among taxa (see review in Thomsen \& Willerslev 2015). In contrast to traditional monitoring surveys, false positive results may occur due to cross-contamination, sequencing errors and largescale transport of genetic traces (e.g. contamination from birds) (Lahoz-Monfort et al. 2015). The effect of environmental factors on eDNA concentration, diffusion and 
advection in natural bodies of water (e.g. the effect of running water on the downstream transportation of eDNA) are also largely unknown. This new population data collection approach is thus challenged by uncertainty related to the environmental effects, samples collection and laboratory procedures. Large-scale studies to test this efficiency and calibrate these methods to detect and quantify population are needed (Roussel et al. 2015).

Environmental DNA surveys may be designed to detect the presence of a single species (species-specific markers) or multiple species (i.e. eDNA metabarcode markers). By allowing the simultaneous sequencing of several million DNA fragments in water samples, eDNA metabarcoding analyses have a huge potential to assess biodiversity of aquatic species (Evans et al. 2015; Valentini et al. 2015). To date, the number of sequences obtained in eDNA metabarcoding does not allow a rigourous evaluation of eDNA concentration in water samples (but see Evans et al. 2015 and Thomas et al. 2016). Yet, a number of eDNA studies have shown positive correlations between the eDNA concentrations obtained from quantitative (qPCR) analyses and population abundance indices (Lacoursière-Roussel et al. 2016a; Lacoursière-Roussel et al. 2016b; Pilliod et al. 2013a; Takahara et al. 2012; Thomsen et al. 2012b; Wilcox et al. 2013). However, the ability to quantify population abundance using eDNA is still debated (Iversen et al. 2015; Roussel et al. 2015; Tréguier et al. 2014) and the relative sensitivity of both methods is largely unknown.

In this study, we aim to evaluate the efficiency of eDNA to detect and quantify amphibian and reptile populations in natural habitats using both single- and multiple- 
species approaches. Species-specific primers with a Taqman probe were developed to detect the Wood turtle (Glyptemys insculpta), a threatened species in Canada (Government of Canada 2015), by means of quantitative PCR (qPCR). The speciesspecific detection rate was then compared to its relative abundance obtained by the standardized visual surveys typically used by managers. Additionally, a pool of multispecies primers has been developed to detect North American amphibian and reptile species by eDNA metabarcoding analyses. Using these primers to collect eDNA samples could help to improve the current poor level of knowledge about distribution ranges and population trends data that currently limits the development of effective conservation strategies for those species.

\section{METHOD}

For species-specific analysis, detection rates obtained by qPCR were compared to the relative abundance of Wood turtle obtained by standardized visual surveys in nine river sections in the Province of Québec (Canada; Figure 1). For multi-species analyses, a eDNA metabarcoding dataset from samples collected in seven lakes and five rivers in Québec was compared to a species occurrence probability index (Canada; Figure 1).

\section{POPULATION AND COMMUNITY ASSESSMENT}

The relative abundance of the Wood turtle was obtained from conventional visual surveys used by managers (Daigle and Jutras 2005). For each sampled river section, visual surveys were conducted by a team of three people walking between 2 and $4 \mathrm{~km}$ of riverbanks between $08 \mathrm{~h} 30$ to $17 \mathrm{~h} 30$. Rivers were surveyed on sunny days with air 
temperature above $15^{\circ} \mathrm{C}$ between April 26th and May 21th 2013, before the complete emergence of vegetation. The total number of turtles during the sampling day was used as an index of relative abundance.

For each of the 34 local amphibian and reptile species (Table S1), an occupancy analysis was conducted to obtain a categorical index of occurrence probability ( 0 to 3 ) for a given species in a given sampling location. This index (hereafter referred to as occurrence index, $i$ ) relies on the probability for a species to be present in a given location based on its distribution range and its habitat preferences. The species distribution range is based on validated species observations included in the Québec Amphibians and Reptiles Atlas database (AARQ 2013). The habitat preferences for each species are based on scientific literature (Desroches and Rodrigue 2004; Dodd 2013a, b; Ernst and Ernst 2003; Ernst and Lovich 2009; Petranka 2010). The occurrence index is 0 when the sampled location is outside of the known distribution range of the species. When the sampled location occurs within the species distribution range, the occurrence index is 1 for terrestrial species like most snakes and the Eastern red-backed salamanders (Plethodon cinereus). The occurrence index is either 2 or 3 for species with at least one aquatic life stage, depending on whether the sampled habitat is included $(i=3)$ or not $(i=2)$ in their preferred habitat types based on scientific literature (Table 1).

\section{eDNA SURVEY}

Water samples were collected between July 22nd and 24th 2013 in sections of nine different rivers and from May 9th to 30th 2013 in seven lakes in Québec (Canada; Figure 
1). Water was collected in the same sections of rivers than the Wood turtle population assessment. Since rivers are shallower and more mixed compared to lakes, the amounts of eDNA are expected to be lower in lotic environments due to a greater degradation rate from UV radiation (Thomsen et al. 2012b). A 2L water sample was therefore taken from rivers in contrast to the $1 \mathrm{~L}$ sample from lakes. Ten water samples, separated by 100-200 $\mathrm{m}$, were collected from each river for species-specific analyses, whereas seven samples randomly chosen were used for eDNA metabarcoding analyses (i.e. an equal number of sites for lakes and rivers for the eDNA metabarcoding; Table S2). The Wood turtle is protected against illegal collection and trade in most of its distribution range in North America (CITES 2015). In accordance with the recommendation of the Committee on the Status of Endangered Wildlife in Canada (COSEWIC), the exact location are not provided for the Wood turtle sampling sites to avoid illegal collection risk. The Wood turtle is not expected to be present in the Mawcook River, but closely related species such as the Common snapping turtle (Chelydra serpentina serpentine) and the Painted turtle (Chrysemys picta) are known to be present, and this river was thus used as a negative control. All waterways were slow-moderate flowing $\left(\leq 3.24 \mathrm{~m}^{3} / \mathrm{s}\right)$, averaging $0.69 \mathrm{~m}$ depth $(\mathrm{SD}=0.41)$ and $12.89 \mathrm{~m}(\mathrm{SD}=5.67)$ of width. In lacustrine systems, water samples were collected in seven lakes (Figure 1). A 1L water sample was taken from a boat at seven locations randomly distributed within each lake. To ensure the homogeneity of the water column, and to increase the similarity of environmental conditions among lakes, sampling was conducted in early spring, before thermal stratification of the lake. To represent the entire water column and reduce stochastic effects, water samples were collected in the form of integrated samples taken from $0-5 \mathrm{~m}$ of depth (i.e. oblique bottle 
filing along the water column) in a non-stratified period of the year.

For both lakes and rivers, water samples were stored on ice until they were filtered in less than 24 hours after collection to minimize eDNA degradation (see delay between sampling and filtration in Table S2). Water samples were filtered through a $1.2 \mu \mathrm{m}$ glass microfiber filter (Whatman $\mathrm{GF} / \mathrm{C}, 47 \mathrm{~mm}$ ) using a peristaltic pump (Cole-Parmer: Masterflex L/S Modular Drive). Sampling and filtration equipment was sterilized between each sample with $10 \%$ chlorine bleach and rinsed with distilled water; this method was found to be efficient for control samples (Lacoursière-Roussel et al. 2016b). After filtration, filters were frozen until eDNA extraction.

\section{MOLECULAR ANALYSES}

To reduce potential laboratory cross-contamination, procedures for eDNA extraction from filters, PCR preparation, PCR and qPCR cycling were all performed in different rooms. Samples from a specific location were all treated together, and the bench space was bleached prior to processing the next lake. Bodies of waters were processed in a randomized order. DNA was extracted using the QIAshredder and DNeasy Blood and Tissue Kit (Qiagen, Inc (Venlo, Netherlands)) method from Goldberg et al. (2011) adapted for Whatman GF/C filters. To isolate and purify eDNA, $450 \mu$ of ATL Buffer and $50 \mu \mathrm{l}$ of Proteinase K (Qiagen) was added to the tubes containing the filter. Tubes were then vortexed and incubated at $56^{\circ} \mathrm{C}$ overnight. After incubation, the filter and lysis solution mixture was centrifuged at 13,000 RPM within a QIAshredder tube, and then aliquoted equally to three different tubes. A total of $400 \mu \mathrm{l}$ of AL Buffer was added to 
each tube, vortexed and incubated at $70^{\circ} \mathrm{C}$ for $10 \mathrm{~min}$. After the incubation, $400 \mu \mathrm{l}$ of ethanol was added and mixed by vortexing. This mixture was then transferred to a DNeasy Mini spin column (Qiagen, Inc) and centrifuged at 13,000 RPM. The spin column filter was washed using $500 \mu \mathrm{l}$ of AW1 Buffer and was centrifuged at 13,000 RPM. Subsequently, the spin column filter was washed again using $500 \mu$ l of AW2 Buffer and centrifuged at 13,000 RPM. Purified DNA was then eluted in $20 \mu \mathrm{l}$ of nuclease-free water, incubated at room temperature for $5 \mathrm{~min}$ and centrifuged at 13,000 rpm. The extracted DNA was then frozen at $-20{ }^{\circ} \mathrm{C}$ until amplification.

\section{Wood turtle semi-quantitative analyses}

Detection rates of Wood turtle obtained by qPCR was calculated by the sum of the total number of positive amplifications for each of the nine river sections (six amplifications per site and ten sites per river section). We used the TaqMan MGB ${ }^{\mathrm{TM}}$ technology with a 7500 Fast Real-Time PCR system (LifeTechnologies), which requires constructing primers and probes to amplify short DNA fragments. Quantitative PCR (qPCR) was used to detect the presence of eDNA due to the increased sensitivity to sequence mismatches in the target DNA compared to traditional PCR (Ellison et al. 2006; Wilcox et al. 2013) and its potential to reduce false negative results compare to result visualized from electrophoresis gel (Lacoursière-Roussel and Bernatchez unpublished data). We developed species-specific primers and probe to amplify the targeted $71 \mathrm{bp}$ of the mitochondrial COI gene (Table 2). To ensure species-specific amplification, primers and probes were designed to optimize the number of mismatches to other reptile species that may coexist in the system, and to optimize the position of the mismatches (i.e. near $3^{\prime}$ 
(Wilcox et al. 2013)). Reads from reptile species known to coexist with Wood turtle were aligned in Geneious 6.0.6 and primers and probe were designed using Primer Express 3.0 software (Life Technologies). The specificity of primers and probe were tested in situ on DNA extracted from tissues of two turtles that may be found in the same river as Wood turtle (i.e. Common snapping turtle (Chelydra serpentine) and Painted turtle (Chrysemys picta)). The final reaction volume was $20 \mu \mathrm{L}$; including $1.8 \mu \mathrm{L}$ of each primer $(10 \mu \mathrm{M})$, $0.5 \mu \mathrm{L}$ probe $(10 \mu \mathrm{M}), 10 \mu \mathrm{L}$ Environmental Master Mix 2.0 (Life Technologies), $3.9 \mu \mathrm{L}$ $\mathrm{diH}_{2} \mathrm{O}$ and $2 \mu \mathrm{L}$ DNA. The qPCR amplification was performed under the following conditions: $2 \mathrm{~min}$ at $50^{\circ} \mathrm{C}, 10 \mathrm{~min}$ at $95^{\circ} \mathrm{C}$, followed by 70 cycles of $15 \mathrm{~s}$ at $95^{\circ} \mathrm{C}$ and $60 \mathrm{~s}$ at $60^{\circ} \mathrm{C}$. Each qPCR plate included three wells that contained all reagents but no DNA template, to serve as a negative control, and three wells that contained all reagents and Wood turtle extracted DNA template, to serve as a positive control. The data collected from the post-PCR read were used to make presence/absence calls. Wood turtle eDNA was called present when the target amplified above the target's threshold (i.e. level of fluorescence) calculated from the Negative Control reactions obtained from the default analysis settings in the 7500 software (Life Technologies). The degree of precision of descriptors should always be chosen with respect to the optimal degree of precision related to the particular ecological phenomenon being studied, and semi-quantitative descriptor should be used when there is a low precision of the measurements (Legendre and Legendre 1998). Here, by avoiding the measurement of the eDNA concentration (here we thus refer to the eDNA quantification as a semi-quantitative analysis), we aimed to avoid bias due to extreme values obtained by the nature of the secretion captured, 
including the physiological source, the state (i.e. intra- or extracellular) and fate (e.g. suspension time) of aqueous macrobial eDNA.

\section{eDNA metabarcoding}

Four pairs of primers were developed to amplify amphibians, whereas two primer sets were developed for reptiles (Table 3; see Table S1 for the species list targeted for each primer). The sequences available for the 34 local amphibian and reptile species were compared for five different genes: mitochondrial cytochrome c oxidase subunit I (COI), cytochrome $b$ (cytb), $12 S, 16 S$ and $18 S$ ribosomal subunits. Including all available sequences from GenBank, BOLD (Ratnasingham and Hebert 2007) and data provided from the BIO Biodiversity Institute of Ontario, University of Guelph (E. Anne Chambers personal communication), 31 species had sequence information on the COI and cytb. Sequences for the $12 \mathrm{~S}, 16 \mathrm{~S}$ and 18 s regions were not available for many species to be considered for primer design; sequences for the $12 \mathrm{~S}$ gene were available for 26 species, sequences for the $16 \mathrm{~S}$ gene (generally partial and related to $12 \mathrm{~S}$ ) were available for 25 species, and the $18 \mathrm{~S}$ gene was only available for 10 species (Table S1). Sequences were aligned in Geneious 6.0.6 (Kearse et al. 2012) and genetically similar species were grouped using the Neighbor-Joining method (Saitou and Nei 1987) with a Tamura-Nei model (Tamura and Nei 1993). The COI sequences were absent only for three species; Pickerel frog (Lithobates palustris) and Ring-necked snake (Diadophis punctatus) that are unlikely to be present within sampling sites, and Spotted salamander (Ambystoma maculatum) which is likely to be present. Therefore, we developed primers amplifying the cytb gene instead for the latter and the closely related species (i.e. primers Amphi_B 
in Table S1). Primers (Table 3) were designed using the PRIMER3Plus software (Untergasser et al. 2012). Primers were tested in vitro using DNA extracted from tissue samples of 29 species including the species with the unknown COI sequences discussed above (see species list Table S1). To increase DNA extraction yield, $180 \mu \mathrm{L}$ ATL buffer was first added to each tissue separately and shaken with a tungsten carbide bead (Qiagen, Germany) at 27 hertz during 1 min using a TissueLyser (Qiagen, Germany). DNA was then extracted from tissue of each species using the DNeasy Blood and Tissue Kit (Qiagen, Germany) following the manufacturer's spin-column protocol. The amplification mixture contained $0.2 \mu \mathrm{L}$ GoTaq Flexi DNA polymerase (ProMega, USA) with $2 \mu \mathrm{L}$ GoTaq Flexi Buffer $5 \mathrm{X}, 0.8 \mu \mathrm{dNTP}, 0.65 \mu 1 \mathrm{MgCL}_{2}, 0.5 \mu \mathrm{l}$ of each primer $(10 \mu \mathrm{M}), 3.84 \mu \mathrm{L} \mathrm{diH}_{2} 0$, and $2.5 \mu \mathrm{L}$ of DNA. For each species, the PCR mixture was denatured at $95^{\circ} \mathrm{C}$ for $2 \mathrm{~min}$, followed by 35 cycles $\left(95^{\circ} \mathrm{C}\right.$ for $45 \mathrm{~s}, 54^{\circ} \mathrm{C}$ for $45 \mathrm{~s}$ and $72^{\circ} \mathrm{C}$ for $45 \mathrm{~s}$ ) and a final elongation at $72^{\circ} \mathrm{C}$ for $5 \mathrm{~min}$.

\section{Library preparation}

DNA amplifications were performed in a two-step dual-indexed PCR approach specifically designed for Illumina instruments by the Plate-forme d'Analyses Génomiques (IBIS, Université Laval). The first PCR was performed with group-specific primers for amplifying the eDNA of the target taxonomic group. The primers were tailed on the 5' end with part of the Illumina TruSeq adaptors. The following oligonucleotide sequences were first used for amplification: ACACTCTTTCCCTACACGACGCTCTTCCGATCT-[forward primers (Table 3)] and GTGACTGGAGTTCAGACGTGTGCTCTTCCGATCT- [reverse primers (Table 3)]. A 
second PCR was performed to attach remaining adaptor sequence (regions that anneal to the flowcell and library specific barcodes). For the second PCR, the generic forward primer was AATGATACGGCGACCACCGAGATCTACAC[index1]ACACTCTTTCCC TACACGAC and the generic reverse primer was CAAGCAGAAGACGGCATACGAGAT[index2]GTGACTGGAGTTCAGACGTGT.

Please note that primers used in this work contain Illumina specific sequences protected by intellectual property (Oligonucleotide sequences (C) 2007-2013 Illumina, Inc. All rights reserved. Derivative works created by Illumina customers are authorized for use with Illumina instruments and products only. All other uses are strictly prohibited).

The first amplification mixture contained $25 \mu \mathrm{L}$ Qiagen MasterMix, $0.5 \mu 1$ of each primer $(10 \mu \mathrm{M}), 22 \mu \mathrm{L} \mathrm{diH}_{2} \mathrm{O}$ and $2 \mu \mathrm{L}$ of DNA. For all samples, the PCR mixture was denatured at $95^{\circ} \mathrm{C}$ for $15 \mathrm{~min}$, followed by 35 cycles $\left(94^{\circ} \mathrm{C}\right.$ for $30 \mathrm{~s}, 54^{\circ} \mathrm{C}$ for $90 \mathrm{~s}$ and $72^{\circ} \mathrm{C}$ for $60 \mathrm{~s}$ ) and a final elongation at $72^{\circ} \mathrm{C}$ for $10 \mathrm{~min}$. For each primer set, seven aliquots were amplified for each lake and river (i.e. one aliquot per sampling site). Products of the seven aliquots $(10 \mu \mathrm{L})$ from the first PCR were pooled for each primer and each lake and river separately. Pooled products were then purified using Axygen PCR clean up kit following the manufacture's recommended protocol and the resulting DNA eluted in $25 \mu \mathrm{L}$ water. Final DNA amplifications were performed in a volume of 24.5 $\mu \mathrm{L}$, including $5 \mu \mathrm{L}$ Q5 buffer, $0.25 \mu \mathrm{L}$ AmpliTaq Q5 DNA Polymerase, $0.5 \mu \mathrm{L}$ dNTP, $2.5 \mu \mathrm{L}$ Illumina adaptor $(10 \mu \mathrm{M}), 12.25 \mu \mathrm{L}$ diH $_{2} 0$ et $4 \mu \mathrm{L}$ PCR1 mixture. The second PCR mixture was denatured at $98^{\circ} \mathrm{C}$ for $30 \mathrm{~s}$, followed by 10 cycles $\left(98^{\circ} \mathrm{C}\right.$ for 15 $\mathrm{s}, 58^{\circ} \mathrm{C}$ for $15 \mathrm{~s}, 72^{\circ} \mathrm{C}$ for $25 \mathrm{~s}$ ) and a final extension at $72^{\circ} \mathrm{C}$ for 2 min. Separate 
barcodes were used for each location and primer separately. The final PCR products were purified using Axygen PCR clean up kit and DNA eluted in $20 \mu \mathrm{L}$ water. Libraries were quantified by PicoGreen and, for each location, samples were pooled in equal molar concentrations to maximize equal sequence depth per sample location. When both the Bioanalyzer (Agilent) and Quant-iT PicoGreen (Life Technologies) did not detect any DNA, 15.0 $\mu \mathrm{L}$ PCR2 mixtures were mixed nonetheless (see Table S3 for the concentration and volume for each primer and locations separately). To avoid sample contamination, manipulations were performed in a decontaminated UV hood with new equipment. Negative controls were included for all PCRs and showed no amplification. Negative controls were not pooled and sequenced, but since some species were detected in samples for which no PCR product was detected (see Table S3-S5), we emphasize that future eDNA metabarcoding studies should sequence negative control as well, especially in the context of predicting species distribution and conservation purposes.

Sequencing was carried out using an Illumina MiSeq (Illumina, San Diego, USA) at the Plateforme d'Analyses Génomiques of the Institut de Biologie Intégrative et des Systèmes (IBIS - Université Laval, Québec City, Canada) using a paired-end MiSeq Reagent Kit V3 (Illumina, San Diego, USA) and following the manufacturer's instructions. For sequencing, the amplicon pool was diluted to $4 \mathrm{nM}$ with molecular grade water, denatured and then sequenced at $10 \mathrm{pM}$ following manufacturer's instructions. Raw sequencing reads were de-multiplexed using the MiSeq Control software v 2.3 into independent libraries for a total of 140, resulting from each primer set for each lake and river sample. De-multiplexed raw sequencing reads were provided in gzip compressed 
Fastq format. Although we performed paired-end sequencing, only the forward sequences were kept due to lower quality observed for some reverse reads, especially the reverse reads for the Wood turtle primers. Run quality was assessed using FastQC version v0.11.3 and the amplified regions of interest showed a mean Fastq quality scores around 38 (see Table S6 for FastQC quality reports). Since the quality over the portion of interest was very good, no sequences were removed based on a quality score. Sequences with ambiguous nucleotides were discarded. Only reads within 5bp of the expected amplicon length were kept. Forward and reverse primers were then trimmed from the sequences based on their expected lengths. Similarity of the studied sequences to these in a database of the species of interest was assessed using BLAST + v2.2.29 available on the website of the National Center for Biotechnology Information (NCBI, http: //www.ncbi.nlm.nih.gov/). Reads with BLAST results showing less than $94 \%$ similarity with the reference databases were removed. Finally, taxon-locality combinations with less than five reads were assumed to have a read count of zero (Schnell et al. 2015), whereas a species with a count of five and more in a specific location was considered as present. Chimeric sequences were not removed, but no ambiguous identification of species had been found. Raw sequences reads were deposited in NCBI's Sequence Read Archive (SRA, http://www.ncbi.nlm.nih.gov/sra) under Accession Number SRP071113.

\section{STATISTICAL ANALYSES}

All statistical analyses were performed using $\mathrm{R}$ 3.0.3. To ensure the independence between water samples for the detection and quantification of the Wood turtle using qPCR, the coefficient of determination $\left(\mathrm{R}^{2}\right)$ was calculated between the number of 
positive amplifications per site and the spatial distribution of this site (i.e. upstream to downstream). Finally, a linear regression was applied to evaluate the relationship between the number of positive amplifications and the relative abundance of the Wood turtle obtained from conventional visual surveys.

The proportion between the number of species detected by next-generation monitoring over the number of species expected was calculated separately for each occurrence index (i) (hereafter referred to as proportion of species detection). This proportion of species detection was then used to assess the sensitivity of the eDNA method to detect species and compare it among locations. To compare the sensitivity of the eDNA method among species, the proportion between the number of locations with positive detection obtained by next-generation monitoring over the numbers of location expected for this species has been also calculated separately for each occurrence index (hereafter referred to as proportion of location detection). Note that missing information did not allow to estimate the occurrence index for Wood turtle in two lakes (Joseph and Légaré) and the Northern dusky salamander (Desmognathus fuscus) in one lake (à la Truite) and, due to the lack of extraction product, no amplification has been done for the primers Amphi_C and Amphi_B for the rivers Jackson and Quilliam respectively (see Table 5). Such predictions of expected presence are commonly used by wildlife managers to recommend specific surveys and protection measures based on a list of species that should be present at a given location. These proportions of presence over expected presence is also used to assess the abundance in the context of species status evaluation. 
Logistic regression was used to evaluate the relationship between the occurrence index and the eDNA metabarcoding dataset using the $g \operatorname{lm}()$ function of the STATS library (R Core Team 2016). Boxplots were first used to illustrate the distribution data of the number of reads obtained for each occurrence index using the geom_boxplot() function of the GGPLOT library (Wickham 2009). To compare the sensitivity of the eDNA method among habitats, a t.test() function of the STATS library was applied to compare the proportion of species detection between lakes and rivers. Similarly, to compare the sensitivity of the eDNA method between species group, a t-test was applied to compare the proportion of location detection between amphibians and reptiles.

\section{RESULTS}

\section{Wood turtle semi-quantitative analyses}

Except for the negative site control (Mawcook River), the qPCR results detected the Wood turtle within all rivers (Table 4; see Table S2 for the number of positive qPCR amplification per site). Wood turtle was not detected in any of the qPCR negative controls. The number of positive amplifications and the spatial upstream-downstream distribution of the samples sites within a given river were not correlated (Table 4). However, the total number of positive amplifications per river was highly correlated with the relative abundance of the Wood turtle obtained from visual surveys (Figure $2 ; R^{2}=$ 0.77, $\left.P=0.002, F=23.0, \mathrm{df}=7 ; \log _{10}(\mathrm{x}+1): R^{2}=0.96, P<0.0001, F=163.8\right)$. Similarly, the number of sites per river with positive amplifications was highly correlated with the relative abundance obtained from visual surveys $\left(\log _{10}(\mathrm{x}+1): R^{2}=0.66, P<\right.$ $0.01, F=13.4, \mathrm{df}=7)$. 


\section{Community analyses}

A total of 17 out of 34 probable species were detected using eDNA metabarcoding analyses: eight frog and toad species (Anura), four species of salamanders (Urodela), three snake species (Squamata) and two turtle species (Testudines; Table 5; Figure 3). Among the 17 species that were not detected, 12 were not expected to be detected $(i=0$ or $i=1$ ). In total, after bioinformatic filtering (Table S4), 249,274 reads were obtained, where 99.8\% were amphibian species (amphibians: 248,890 reads; reptiles: 384 reads; see Table S5 for the number of reads for each primer and location separately). No amplification was detected in PCR negative controls. Despite the fact that a greater number of lakes were surveyed than rivers — albeit with an equal number of sites-, a greater number of species were detected and a greater number of sequences were found in rivers (5-10 species; 208,188 sequences representing $83.5 \%$ of the total reads) than in lakes (1-5 species; 41086 sequences, 16.5\% total reads; Table 5). Amphibians were found in all sampled lakes and rivers. Northern green frog (Lithobates clamitans melanota) was the most represented species in terms of the number of locations (i.e. 5 of 7 sampled lakes and all rivers) and the number of sequences (180,960 total reads); 96.2\% sequences were found in rivers $(174,020$ reads in rivers $v s .6,940$ reads in lakes). The three snake species were found in one lake (i.e. Redbelly snake (Storeria occipitomaculata)) and two rivers (i.e. Northern watersnake (Nerodia sipedon) and Milksnake (Lampropeltis triangulum)). The two turtle species were found in three rivers (Snapping turtle (Chelydra serpentine) and Wood turtle). The Wood turtle was not 
detected in four rivers where it was expected to be found based on the qPCR results and visual surveys presented above.

As expected, species with a higher occurrence index were more often detected than species with a lower occurrence index (logistical regression: $P<0.0001$, $t$ ratio $=6.30$, Residual deviance $=245.03, d f=386$; Figure 4 ). Ten species with a high occurrence index $(i=3)$ were detected (see the species list in Table 5 row proportion of location $i=$ 3), representing $70.4 \%$ of the positive detections and a total of 234,667 reads. Only three species were not detected despite having a high probability of being detected (i.e. $i=3$; Northern watersnake (Nerodia sipedon), Northern dusky salamander (D. fuscus) and Painted Turtle (Chrysemys picta) in two, three and 12 locations respectively). Four Anuran species (13,792 reads) and three salamander species (476 reads) were detected in aquatic habitats which are not included in their preferred habitat types (i.e. see the species list in Table 5; proportion of location $i=2$ ). This represented $24.1 \%$ of the positive detections. Two terrestrial species were detected (i.e. $i=1: 63$ reads of the Red-bellied snake (Storeria occipitomaculata) in the Joseph lake and 186 reads of the Milksnake (Lampropeltis triangulum) in the North Branch river). This represented $3.7 \%$ of the positive detections. A single species out of its expected spatial distribution range was found (i.e. $i=0: 90$ reads for the Northern watersnake in the Quilliams River), which represented $1.9 \%$ of the positive detections. GenBank BLAST supported that a unique mismatch in the identified sequence was probably due to intraspecific variability (i.e. 98.91\% similarity), and the Northern watersnake was the species with the closest match to the sequence. 
The eDNA metabarcoding approach was more sensitive for rivers than lakes and for amphibians than reptiles. Species with a high occurrence index $(i=3)$ were more often detected in rivers than lakes (proportion of species detection averaged $45.2 \%$ and $23.7 \%$ for rivers and lakes respectively; t-test $P=0.01, t=-3.14, d f=9.9$; Table 5). The proportion of location detection was greater for amphibians than reptiles (the average was $49.3 \%$ and $6.3 \%$ for amphibians and reptiles respectively; t-test: $P=0.005$; see Table 5 for the proportions for each species detected). Similarly, amphibians with moderate occurrence index $(i=2)$ were also more detected in rivers than lakes (proportion of location detection averaged $24.6 \%$ and $8.3 \%$ in rivers and lakes respectively; t-test: $P=$ $0.008, t=-3.60, d f=7.7)$.

\section{DISCUSSION}

\section{Increasing spatial distribution knowledge}

Improvement of data on distribution range, presence, abundance and population trends is a major goal of several recovery plans for amphibian and reptile species (Campbell et al. 2002; Lovett et al. 2007; Pavey 2004). Our results empirically support the effectiveness of the eDNA method to trace the presence of both amphibian and reptile species. The only inconsistency between the occurrence index and the eDNA metabarcoding dataset was the detection of the Northern watersnake outside of its known distribution range in the Quilliams River. Interestingly, an observation of watersnake by a landowner was reported in 2015 in the same river section where water samples were collected in 2013 (Michel Delorme pers. comm). It was not considered as a valid observation because there 
was no photographic evidence and the location was approximately $50 \mathrm{~km}$ east from the known distribution range. This positive detection out of the known distribution range may help to identify sites for surveying to refine our sparse knowledge on this species. This species is likely to be designated threatened or vulnerable by provincial government in the coming years.

\section{Effect of natural habitats on detection rates}

Little is known about the origin (i.e. extracellular DNA fragments, mitochondria, cells, excretion or eggs) and the dispersion of eDNA in natural ecosystems. Environmental conditions are likely to alter eDNA detection rates due to vertical and horizontal transport (advection and diffusion) and its effect on the eDNA release and degradation rates (Dejean et al. 2011; Pilliod et al. 2013b). Without significant water flow, horizontal eDNA transport is expected to be limited due to the fact that eDNA collected from water samples has been suggested to be from cells and mitochondria that will rapidly sink to the bottom of the water body (Barnes et al. 2014; Turner et al. 2014; Turner et al. 2015). Low eDNA transport distances could thus potentially explain the lowest number of species and number of sequences detected in lakes compared to rivers, where eDNA is expected to be transported over large distances by currents (Deiner and Altermatt 2014; Jane et al. 2015). A lack of eDNA diffusion in stagnant water would mean that the sampling design needs to consider taking the samples at the exact site where the genetic material is released. Nevertheless, amphibian and reptile traces have been detected in lakes despite the fact that the sampling was not occurring on the edge of the lakes (i.e. where eDNA traces would have been expected to be higher). This result may underline a greater diffusion of 
eDNA than is expected, at least for abundant secretory animals such as amphibians (i.e. from moulting, mucus, larvae stage). However, due to the variability of environmental conditions, the ability to track eDNA of terrestrial species could potentially vary during seasons and might be higher during spring when the lacustrine environment is well-mixed. Therefore, the eDNA catchability may depend on water column stratification and horizontal sampling location in lakes, whereas the eDNA in rivers may represent a much larger scale of sampling given the flow of water allowing integration over space (Cannon et al. 2015; Deiner et al. 2015). To overcome a potentially greater eDNA degradation in rivers than lakes (Thomsen et al. 2012b), we doubled the volume of water that was filtered in river compared to lakes, but the environmental conditions may also have increased degradation rate in lakes compared to rivers (e.g. humic acid and tannin). A better understanding of eDNA diffusion and advection in large natural habitats is essential to optimize detection rates.

\section{Variability of detection rates among species groups}

Among species with a high occurrence index, detection rate was higher for amphibians compared to reptiles. This may be due to differences in life history traits (e.g. aquatic, high secretion rates such as mucus and moulting, eggs and larvae in the aquatic habitat $v s$. terrestrial eggs for turtles) and population density (Lacoursière-Roussel et al. 2016a; Mahon et al. 2013; Pilliod et al. 2013a; Takahara et al. 2012; Thomsen et al. 2012b). For example, the three species with the greatest detection rates were: Northern two-lined salamander, Eurycea bislineata, found in $100 \%$ of the sampled locations where they were expected to be present (3/3 rivers), Northern green frog (Lithobates (Rana) clamitans 
melanota) found in $83.3 \%$ of the sampled locations (10/12 locations) and the American toad (Anaxyrus (Bufo) americanus) found in $75.0 \%$ of the sampled locations (3/4 rivers) (Table 5). These species are known to be common, aquatic for all their life cycle with a high occupancy rate and may reach high abundance (Desroches and Rodrigues 2004; AARQ 2013). The Northern green frog is the species with the highest occurrence index and likely the highest abundance in our sample sites, and had the greatest total number of sequences. The larval development (tadpoles) of the Northern green frog can last up to two years (Desroches and Rodrigue 2004; Dodd 2013b). A high number of tadpoles could potentially explain the high levels of DNA detected. Moreover, since eDNA sampling in rivers occurred in July during spawning of the Northern green frog which occurs from June to August (Desroches and Rodrigue 2004), there was potentially a high number of eggs (i.e. high levels of genetic material with the mass of gelatin and the 14005300 eggs per spawning) and newly hatched tadpoles in the bodies of water at the sampling time. On the contrary, water sampling in lakes, where the proportion of species detection is lower than in rivers, was realized in early spring when the metabolism of amphibians is still slowed down by cold water and the reproduction activities of amphibian species commonly present in lakes has not begun.

\section{Specific vs. multi-species approach}

Similar to conventional inventory methods, the eDNA method may generate false negatives due to limited sampling effort, but also due to limitations in the power of detection. The eDNA metabarcoding approach detected the presence of Wood turtle in only one of the five rivers whereas it was detected within all five rivers using quantitative 
PCR (qPCR), which was therefore more sensitive than the eDNA metabarcoding monitoring. As it amplifies shorter DNA fragments (i.e. $71 \mathrm{bp}$ DNA sequence for qPCR analyses vs. $167 \mathrm{bp}$ sequence for eDNA metabarcoding analyses), qPCR may detect more highly degraded organic matter (Barnes et al. 2014; Dejean et al. 2011; Hajibabaei et al. 2006), thus improving detection ability. Although qPCR was more accurate and faster than next-generation monitoring for species-specific studies, eDNA metabarcoding still provided a powerful tool to screen the presence of herpetological species, including in habitats that have not been surveyed due to limited resources.

To date, the number of sequences obtained by eDNA metabarcoding cannot rigorously be related to species abundance, or even the number of DNA molecules in the water environment. This may be due to several factors, including: (i) the disproportionate amplification from unequal primers binding among species, (ii) the non-linearity of the amplifications during the PCR, (iii) the variability induced by the multiple manipulations (e.g. multiple beads purification), or (iv) the variability in pooling accuracy to collect similar numbers of reads among water bodies. The result of primer competition during the amplification is difficult to predict since it depends on the community composition and the relative abundance of each species. Moreover, the number of DNA copies does not increase linearly during the PCR cycles, whereby it first increases exponentially and then reach a saturation plateau. Thus, despite the fact that the number of PCR cycles was equal among samples and primers, the number of amplified strands may vary significantly among species and samples as a function of the kinetics process during the PCR reactions. PCR initiation could be altered by the length, the sequence and the ionic 
composition of the primer sets, as well as the occurrences of primer dimers (Higuchi et al. 1993; Liu and Saint 2002). The effect of the primer length should be studied, but here and likely most of the similar studies - we preconized longer length of the primer-probe sets for qPCR analyses to ensure the specificity of the amplification $\left(\mathrm{N}_{\text {total }}=69 \mathrm{bp}\right)$ whereas shorter primer sets were used to optimize the amplification of overall species group for metabarcoding analyses $\left(\mathrm{N}_{\text {total }}=37 \mathrm{bp}\right)$. To the best of our knowledge, in nature, eDNA metabarcoding monitoring can only provide relative abundance indices based on the species detection rate from spatial replication with similar community composition and relative abundance in habitats with similar environmental conditions. However, Evans et al. (2015) showed a tendency to predict the abundance of species in mesocosm experiments based on eDNA metabarcoding results and Thomas et al. (2016) recently suggested that quantitative DNA metabarcoding may provide estimate of proportional biomass when relative correction factors are applied. Therefore, more studies are needed to determine the limit of eDNA metabarcoding to provide abundance indices and intraand inter-specific variability of the eDNA release rate.

\section{The use of eDNA as a quantitative tool}

A salient result of our study was that eDNA semi-quantitative results obtained by qPCR were highly correlated with the relative abundance of Wood turtle obtained by visual surveys. Here we used a semi-quantitative method (i.e. number of positive amplifications) instead of evaluating the eDNA concentration to predict population abundance from eDNA concentration (Lacoursière-Roussel et al. 2016a; LacoursièreRoussel et al. 2016b; Pilliod et al. 2013a; Takahara et al. 2012; Thomsen et al. 2012b; 
Wilcox et al. 2013). Similar to traditional methods, the eDNA method requires a sampling design adapted to the ecology of the species sought, but the eDNA concentration may also largely vary as a function of extreme measurements of eDNA concentration hypothetically caused by sampling cells, other organic tissues or suspension sediment. Organic tissues or suspended sediment may potentially lead to abundance overestimation. Within a specific site, the eDNA concentration is thus likely to vary according to the rate of DNA released by individuals (inter-species variability, metabolic activity and size of animals), and the environmental conditions (temperature, radiation and water flow) (Barnes et al. 2014; Lacoursière-Roussel et al. 2016b). In contrast to the eDNA concentration, the number of positive amplifications provides evidence of a recent presence of the targeted species near the sampling area, and is likely to bring a more similar result to visual surveys, as suggested by our results. The maximum value is likely to be reached by a close-targeted individual or by multiple distanced individuals. In contrast, predicting population abundance based on the estimation of the eDNA concentration within a body of water is based on the assumption that higher individual densities release more eDNA within the system. A semiquantitative eDNA detection is based on the assumption that a greater number of specimens will distribute the eDNA more homogeneously within water bodies, thereby increasing the probability of eDNA detection when surveying large aquatic systems. However, this semi-quantitative eDNA method is not likely to be applicable to well mixed environments (e.g. ponds) or for aggregated species.

\section{Increasing local genetic knowledge to improve eDNA species monitoring}


Amphibian and reptile species are known to be genetically very divergent among species and even among geographical regions within species (Thomsen et al. 2012b; Vences et al. 2012; Vences et al. 2005). Despite the fact that the amplification of COI is often desirable to differentiate the species using the standard DNA barcoding procedures (Che et al. 2012), COI sequences are still often absent for amphibians and reptiles (Murphy et al. 2013). Here COI sequences for many amphibians and reptiles were still absent from public databases and the available sequences were not from individuals collected in Québec. Increasing our local knowledge of the genetic divergence of amphibians and reptiles of Québec at the COI locus would potentially improve the alignment of sequences (i.e. $>94 \%$ similarity with the reference databases) and consequently improve the reliability of the eDNA metabarcoding analyses for herpetological monitoring. A set of mitochondrial $12 \mathrm{~S}$ primers developed by Valentini et al. (2015) is expected to amplify all amphibians. Here, the $12 \mathrm{~S}$ sequences were currently missing for four of the 19 amphibian species. Further studies are therefore needed to validate the efficiency of these primers for North American amphibian species. Sequencing a large number of individuals for each species from different regions is a crucial component to develop large-scale standardized eDNA monitoring programs and to ensure the successful implementation of the eDNA method within conservation strategies.

\section{The potential of eDNA to improve herpetological conservation strategies}

For Wood turtle, the standardized visual surveys were limited to a single month during the spring between 9 am and 4 pm on a sunny day (Bernier and Mazerolle 2009), but eDNA samples provided similar population abundance data in July, potentially increasing the time window for data collection. One challenge to increase knowledge about the 
population range of rare species is to decrease time needed to survey a given site and to increase the number of sites sampled (Dodd and Dorazio 2004). Environmental DNA offers the potential to facilitate species at risk monitoring because water sampling is faster than several traditional survey techniques and may increase the probability of detection (Dejean et al. 2012; Jerde et al. 2011; Pilliod et al. 2013a; Smart et al. 2015). The eDNA also requires less work from expert taxonomists, for instance to identify species at various developmental stage (e.g. eggs and larvae).

Conventional methods used to document presence of species and to monitor population trends within a given distribution range are based on presence/absence and/or count data to estimate abundance and occupancy (Mazerolle et al. 2007). Our results provide an empirical demonstration of the effectiveness of the eDNA method to efficiently characterize the presence of amphibians and reptiles in natural environments and show that eDNA may provide quantitative data comparable to measurement obtained by classical visual surveys. The extension or contraction of distribution ranges is one indicator of a species trend (Erb et al. 2015; Mackenzie et al. 2002; Zylstra E.R. et al. 2010) and is a common indicator in recovery plan objectives (e.g. Environment Canada 2014). Environmental DNA can be used to define species range data from different habitats and merge sampling efforts when resources are limited. Despite that future work is needed to improve the detection rate of amphibians and reptiles yet, eDNA already represents a powerful tool for managers as a first step towards rapidly assessing species occurrence and to some extent their relative abundance. 


\section{ACKNOWLEDGEMENTS}

We thank Simon Pelletier for turtle survey planning and for sampling water in rivers, the Organisme de bassin versant de la Yamaska and Appalachian Corridor for conducting turtle survey, and the regional MFFP teams for water sampling in lakes. We are grateful to Guillaume Côté for his help for the qPCR amplifications, Cecilia Hernandez for her help to design primers and for the success of the eDNA metabarcoding amplifications, and Ben Sutherland for text editing. Thank you also to Brian Boyle and the team of bioinformatics platform of the l'Institut de Biologie Intégrative et des Système (IBIS) for sequencing and assist the development of the project, Robert Hanner and E. Anne Chambers from the Biodiversity Institute of Ontario (U. Guelph) for providing the COI sequences, Nathalie Tessier (MFFP), Cindy Bouchard (Université de Montréal), Bob Murphy, Amy Lathrop and Erling Holm (Royal Ontario Museum (ROM)) for providing amphibian and reptile tissues and François Gouge for allowing us to sample the eDNA turtles from the Aquarium of Québec to test primers and calibrate the method. We are also grateful to the Guest Editor Sarah Adamowicz, the Associate Editor Kristy Deiner and two anonymous referees for their constructive comments on a previous version of the manuscript. This project is part of a collaboration between the Québec government (Ministère des Forêts, de la Faune et des Parcs, MFFP), who funded the study and provided the occurrence index and water samples, and the Canada Research Chair in Genomics and Conservation of Aquatic Resources led by L.B.. A.L.R. was funded by a postdoctoral fellowship of the Fonds de recherche Nature et technologies du Québec. 


\section{REFERENCES}

Alroy, J. 2015. Current extinction rates of reptiles and amphibians. PNAS 112: 1300313008.

Atlas des Amphibiens et des Reptiles du Québec (AARQ). 2013. Available from http://www.atlasamphibiensreptiles.qc.ca/.

Bailey, L.L., Simons, T.R., and Pollock, K.H. 2004a. Estimating detection probability parameters for Plethodon salamanders using the robust capture-recapture design. J. Wildl. Manage. 68: 1-13. doi: http://dx.doi.org/10.2193/0022-

\section{X(2004)068\%5B0001:EDPPFP\%5D2.0.CO;2.}

Bailey, L.L., Simons, T.R., and Pollock, K.H. 2004b. Estimating site occupancy and species detection probability parameters for terrestrial salamanders. Ecol. Appl. 14: 692702. doi: http://dx.doi.org/10.1890/03-5012.

Baillie, J.E., Griffiths, M., Turvey, J., Loh, S.T., and Collen, B. 2010. Evolution lost: status and trends of the world's vertebrates. Zoological Society of London, London. Barnes, M.A., Turner, C.R., Jerde, C.L., Renshaw, M.A., Chadderton, W.L., and Lodge, D.M. 2014. Environmental conditions influence eDNA persistence in aquatic systems. Environ. Sci. Technol. 48(3): 1819-1827.

Bernier, P.A., and Mazerolle, M.J. 2009. Guide de suivi des populations de tortues des bois (Glyptemys insculpta) au Québec. Ministère des Ressources Naturelles et de la Faune.

Böhm, M., Collen, B., Baillie, J.E.M., Bowlesc, P., Chansond, J., Coxc, N., Hammersonf, G., Hoffmanng, M., Livingstoneh, S.R., Rama, M., Rhodini, A.G.J., Stuartj, S.N., van Dijkl, P.P., Youngo, B.E., Afuangp, L.E., Aghasyanq, A., Garcíar, A., Aguilars, C., Ajtict, R., Akarsuu, F., Alencarv, L.R.V., Allisonw, A., Ananjevax, N., Andersony, S., Andrénz, 
C., Ariano-Sánchezaa, D., Arredondoab, J.C., Auliyaac, M., and Austinad, C.C. 2013. The conservation status of the world's reptiles. Biol. Conserv. 157: 372-385. doi: http://dx.doi.org/10.1016/j.biocon.2012.07.015.

Campbell, S.P., Clark, J.A., Crampton, L.H., Guerry, A.D., Hatch, L.T., Hosseini, P.R., Lawler, J.J., and O'Connor, R.J. 2002. An assessment of monitoring efforts in endangered species recovery plans. Ecol. Appl. 12: 674-681.

Cannon, M., Hester, J., Shalkhauser, A., Chan, E.R., Logue, K., Small, S.T., and Serre, D. 2015. Deep sequencing of environmental DNA isolated from the Cuyahoga River highlights the utility of river water samples to query surrounding aquatic and terrestrial biodiversity. BioRxiv. doi: http://dx.doi.org/10.1101/027235

Che, J., Chen, H.-M., Yang. J.-X., Jin, J.-Q., Jiang, K., Yuan, Z.-Y., Murphy, R.W., and Zhang, Y.-P. 2012. Universal COI primers forDNA barcoding amphibians. Mol. Ecol. Resour. 12: 247-258. doi: 10.1111/j.1755-0998.2011.03090.x. Convention on International Trade in Endangered Species of wild fauna and flora (CITES). 2015. Appendices II. Available from http://www.cites.org. Couturier, T., Cheylan, M., Bertolero, A., Astruc, G., and Besnard, A. 2013. Estimating abundance and population trends when detection is low and highly variable: A comparison of three methods for the Hermann's tortoise. J. Wildl. Manage. 77: 454-462. Daigle, C., and Jutras, J. 2005. Quantitative evidence of decline in a southern Québec wood turtle (Glyptemys insculpta) population. J. Herpetol. 39: 130-132.

Davy, C.M., Kidd, A.G., and Wilson, C.C. 2015. Development and validation of the environmental DNA (eDNA) markers for detection of freshwater turtles. PLoS One 10(7): e0130965. doi: 10.1371/journal.pone.0130965. 
de Solla, S.R., Shirose, L.J., Fernie, K.J., Barrett, G.C., Brousseau, C.S., and Bishop, C.A. 2005. Effect of sampling effort and species detectability on volunteer based anuran monitoring programs. Biol. Conserv. 121: 585-594.

Deiner, K., and Altermatt, F. 2014. Transport distance of invertebrate environmental DNA in a natural river. PLoS One 9(2): e88786. doi: 10.1371/journal.pone.0088786

Deiner, K., Fronhofer, E.A., Mächler, E., and Altermatt, F. 2015. Environmental DNA reveals that rivers are conveyer belts of biodiversity information. bioRxiv. doi: http://dx.doi.org/10.1101/020800

Dejean, T., Valentini, A., Duparc, A., Pellier-Cuit, S., Pompanon, F., Taberlet, P., and Miaud, C. 2011. Persistence of environmental DNA in freshwater ecosystems. PLoS One 6(8): e23398. doi: 10.1371/journal.pone.0023398.

Dejean, T., Valentini, A., Miquel, C., Taberlet, P., Bellemain, E., and Miaud, C. 2012. Improved detection of an alien invasive species through environmental DNA barcoding: the example of the American bullfrog Lithobates catesbeianus. J. Appl. Ecol. 49(4): 953959. doi: Doi 10.1111/J.1365-2664.2012.02171.X.

Desroches, J., and Rodrigue, D. 2004. Amphibiens et reptiles du Québec et des Maritimes. Guides nature Quintin., Waterloo, Canada.

Dodd, C.K., and Dorazio, R.M. 2004. Using counts to simultaneously estimate abundance and detection probabilities in a salamander community. Herpetologica 60(4): 468-478.

Dodd, C.K.J. 2013a. Frogs of the United States and Canada. Volume 1. The Johns Hopkins University Press, Baltimore, USA. 
Dodd, C.K.J. 2013b. Frogs of the United States and Canada. Volume 2. The Johns Hopkins University Press, Baltimore, USA.

Ellison, S.L.R., English, C.A., Burns, M.J., and Keer, J.T. 2006. Routes to improving the reliability of low level DNA analysis using real-time PCR. Bmc Biotechnology 6: 33. doi: $10.1186 / 1472-6750-6-33$.

Environment Canada. 2014. Recovery Strategy for the Allegheny Mountain Dusty Salamander (Desmognathus ochrophaeus), Great Lakes/St. Lawrence Population, in Canada. Species at Risk Act Recovery Strategy Series. Environment Canada, Ottawa. Erb, L.A., Willey, L.L., Johnson, L.M., Hines, J.E., and Cook, R.P. 2015. Detecting longterm population trends for an elusive reptile species. J. Wildl. Manage. 79: 10.

Ernst, C.H., and Ernst, E.M. 2003. Snakes of the United States and Canada, Washington and London. pp. 668.

Ernst, C.H., and Lovich, J.E. 2009. Turtles of the United States and Canada. Second edition. Johns Hopkins University Press, Baltimore, Maryland.

Evans, N.T., Olds, B.P., Renshaw, M.A., Turner, C.R., Li, Y., Jerde, C.L., Mahon, A.R., Pfrender, M.E., Lamberti, G.A., and Lodge, D.M. 2015. Quantification of mesocosm fish and amphibian species diversity via environmental DNA metabarcoding. Mol. Ecol.

Resour. doi: 10.1111/1755-0998.12433.

Ficetola, G.F., Miaud, C., Pompanon, F., and Taberlet, P. 2008. Species detection using environmental DNA from water samples. Biology Letters 4: 423-425. doi:

10.1098/Rsbl.2008.0118. 
Gibbons, J.W., Scott, D.E., Ryan, T.J., Buhlmann, K.A., Tuberville, T.D., Metts, B.S., Greene, J.L., Mills, T., Leiden, Y., Poppy, S., and Winne, C.T. 2000. The global decline of reptiles, déjà vu amphibiens. BioScience 50: 653-666.

Goldberg, C.S., Pilliod, D.S., Arkle, R.S., and Waits, L.P. 2011. Molecular detection of vertebrates in stream water: a demonstration using rocky mountain tailed frogs and idaho giant salamanders. PLoS One 6(7). doi: 10.1371/journal.pone.0022746.

Haile, J., Froese, D.G., MacPhee, R.D.E., Roberts, R.G., Arnold, L.J., Reyes, A.V., Rasmussen, M., Nielsen, R., Brook, B.W., Robinson, S., Demuro, M., Gilbert, M.T.P., Munch, K., Austin, J.J., Cooper, A., Barnes, I., Moller, P., and Willerslev, E. 2009. Ancient DNA reveals late survival of mammoth and horse in interior Alaska. Proc. Natl. Acad. Sci. U. S. A. 106(52): 22352-22357. doi: Doi 10.1073/Pnas.0912510106. Hajibabaei, M., Smith, M.A., Janzen, D.H., Rodriguez, J.J., Whitfield, J.B., and Hebert, P.D.N. 2006. A minimalist barcode can identify a specimen whose DNA is degraded. Mol. Ecol. Notes 6: 959-964.

Higuchi, R., Fockler, C., Dollinger, G., and Watson, R. 1993. Kinetic PCR analysis: realtime monitoring of DNA amplification reaction Biotechnology 11: 1026-1030.

Houlahan, J.E., Findlay, C.S., Schmidt, B.R., Meyer, A.H., and Kuzmin, S.L. 2000. Quantitative evidence for global amphibian population declines. Nature 404: 752-755. Howard, S.D., and Bickford, D.P. 2014. Amphibians over the edge: silent extinction risk of Data Deficient species. Divers. Distrib. 20: 837-846.

International Union for Conservation of Nature and Natural Resources (IUCN). 2016. Red List version 2016-1 : Table 3a. Available from 
http://cmsdocs.s3.amazonaws.com/summarystats/2016-

1 Summary Stats Page Documents/2016 1 RL Stats Table 3a.pdf.

Iversen, L.L., Kielgast, J., and Sand-Jensen, K. 2015. Monitoring of animal abundance by environmental DNA — An increasingly obscure perspective: A reply to Klymus et al., 2015. Biol. Conserv. doi: 10.1016/j.biocon.2015.09.024.

Jane, S.F., Wilcox, T.M., McKelvey, K.S., Young, M.K., Schwartz, M.K., Lowe, W.H., Letcher, B.H., and Whiteley, A.R. 2015. Distance, flow, and PCR inhibition: eDNA dynamics in two headwater streams. Mol. Ecol. Resour. 15: 216-227. doi: 10.1111/17550998.12285 .

Jerde, C.L., Chadderton, W.L., Mahon, A.R., Renshaw, M.A., Corush, J., Budny, M.L., Mysorekar, S., and Lodge, D.M. 2013. Detection of Asian carp DNA as part of a Great Lakes basin-wide surveillance program. Can. J. Fish. Aquat. Sci. 70: 1-5. doi: dx.doi.org/10.1139/cjfas-2012-0478.

Jerde, C.L., Mahon, A.R., Chadderton, W.L., and Lodge, D.M. 2011. "Sight-unseen" detection of rare aquatic species using environmental DNA. Conservation Letters 4(2): 150-157. doi: 10.1111/J.1755-263x.2010.00158.X.

Kearse, M., Moir, R., Wilson, A., Stones-Havas, S., Cheung, M., Sturrock, S., Buxton, S., Cooper, A., Markowitz, S., Duran, C., Thierer, T., Ashton, B., Mentjies, P., and Drummond, A. 2012. Geneious Basic: an integrated and extendable desktop software platform for the organization and analysis of sequence data. Bioinformatics 28(12): $1647-1649$. 
Lacoursière-Roussel, A., Côté, G., Leclerc, V., and Bernatchez L. 2016a. Quantifying relative fish abundance with eDNA: a promising tool for fisheries management. J. Appl. Ecol. doi: 10.1111/1365-2664.12598.

Lacoursière-Roussel, A., Rosabal, M., and Bernatchez, L. 2016b. Estimating fish abundance and biomass from eDNA concentrations: variability among capture methods and environmental conditions. Mol. Ecol. Resour.

Lahoz-Monfort, J.J., Guillera-Arroita, G., and Tingley, R. 2015. Statistical approaches to account for false positive errors in environmental DNA samples. Mol. Ecol. Resour. doi: 10.1111/1755-0998.12486.

Legendre, P., and Legendre, L. 1998. Numerical Ecology, 2nd edition, Developments in Environmental Modelling 20, Elsevier, New York. pp. xv +853 pages.

Lind, A.J., Welsh Jr, H.H., and Tallmon, D.A. 2005. Garter snake population dynamics from a 16-year study: considerations for ecological monitoring. Ecol. Appl. 15: 294-303. Liu, W., and Saint, D.A. 2002. Validation of aquantitative method for real time PCR kinetics. Biochem. Biophys. Res. Commun. 294: 347-353.

Lodge, D.M., Turner, C.R., Jerde, C.L., Barnes, M.A., Chadderton, L., Egan, S.P., Feder, J.L., Mahon, A.R., and Pfrender, M.E. 2012. Conservation in a cup of water: estimating biodiversity and population abundance from environmental DNA. Mol. Ecol. 21(11): 2555-2558. doi: 10.1111/J.1365-294x.2012.05600.X.

Lovett, G.M., Burns, D.A., Driscoll, C.T., Jenkins, J.C., Mitchell, M.J., Rustad, L., Shanley, J.B., Likens, G.E., and Haeuber, R. 2007. Who needs environmental monitoring? Front. Ecol. Environ. 5: 253-260. 
Lydolph, M.C., Jacobsen, J., Arctander, P., Gilbert, M.T.P., Gilichinsky, D.A., Hansen, A.J., Willerslev, E., and Lange, L. 2005. Beringian paleoecology inferred from permafrost-preserved fungal DNA. Appl. Environ. Microbiol. 71: 1012-1017. Mackenzie, D.I., Nichols, J.D., Lachman, G.B., Droege, S., Royle, J.A., and Langtimm, C.A. 2002. Estimating site occupancy rates when detection probabilities are less than one. Ecology 83(8): 2248-2255.

Mahon, A.R., Jerde, C.L., Galaska, M., Bergner, J.L., Chadderton, W.L., Lodge, D.M., Hunter, M.E., and Nico, L.G. 2013. Validation of eDNA surveillance sensitivity for detection of Asian carps in controlled and field experiments. PLoS One: e58316. doi: 10.1371/journal.pone.0058316.

Massachusetts Cooperative Fish and Wildlife Research Unit and the Northeast Wood Turtle Working Group. 2013. Coordinated Monitoring Strategy for Wood Turtles (Glyptemys insculpta) in the Northeastern United States. V 5.0 January 28, 2013. . Mazerolle, M.J., Bailey, L.L., Kendall, W.L., Royle, J.A., Converse, S.J., and Nichols, J.D. 2007. Making great leaps forward : Accounting for dectectability in herpetological field studies. J. Herpetol. 41(4): 672-689.

Murphy, B.W., Crawford, A.J., Bauer A.M., Che, J., Donnellan, S.C., Fritz, U., Haddad, C.F.B., Nagy, Z.T., Poyarkov, N.A., Vences, M., Wang W.-Z., and Zhang, Y.-P. 2013. Cold Code: the global initiative to DNA barcode amphibians and nonavian reptiles. Mol. Ecol. Resour. 13: 161-167. doi: 10.1111/1755-0998.12050.

Pavey, C. 2004. Recovery plan for Slater's Skink, Egernia slateri, 2005-2010.

Pellet, J., and Schmidt, B.R. 2005. Monitoring distributions using call surveys: estimating site occupancy, detection probabilities and inferring absence. Biol. Conserv. 123: 27-35. 
Petitot, M., Manceau, N., Geniez, P., and Besnard, A. 2014. Optimizing occupancy surveys by maximizing detection probability: application to amphibian monitoring in the Mediterranean region. Ecology and Evolution 4(18): 3538-3549.

Petranka, J.W. 2010. Salamanders of the United States and Canada. Smithsonian Institution Press, Washington, D.C.

Pilliod, D.S., Goldberg, C.S., Arkle, R.S., and Waits, L.P. 2013a. Estimating occupancy and abundance of stream amphibians using environmental DNA from filtered water samples. Can. J. Fish. Aquat. Sci. 70(8): 1123-1130. doi: 10.1139/Cjfas-2013-0047. Pilliod, D.S., Goldberg, C.S., Arkle, R.S., and Waits, L.P. 2013b. Factors influencing detection of eDNA from a stream-dwelling amphibian. Mol. Ecol. Resour. 14: 109-116. doi: $10.1111 / 1755-0998.12159$.

Price, S.J., Eskew, E.A., Cecala, K.K., Browne, R.A., and Dorcas, M.E. 2012. Estimating survival of a streamside salamander: importance of temporary emigration, capture response, and location. Hydrobiologia 679: 205-215.

R Core Team. 2016. R: A language and environment for statistical computing. R Foundation for Statistical Computing, Vienna, Austria. Available from: https://www.Rproject.org/.

Ratnasingham, S., and Hebert, P. 2007. BOLD: The Barcode of Life Data System (http://www.barcodinglife.org). Mol. Ecol. Notes 7: 355-364. doi: 10.1111/j.14718286.2006.01678.x.

Roussel, J.-M., Paillisson, J.-M., Treguier, A., and Petit, E. 2015. The downside of eDNA as a survey tool in water bodies. J. Appl. Ecol. 52: 823-826. doi: 10.1111/13652664.12428. 
Saitou, N., and Nei, M. 1987. The neighbor-joining method: a new method for reconstructing phylogenetic trees. Mol. Biol. Evol. 4 406-425.

Schnell, I.B., Bohmann, K., and Gilbert, M.T.P. 2015. Tag jumps illuminated - reducing sequence-to-sample misidentifications in metabarcoding studies. Mol. Ecol. Resour. 15(6): 1289-1303. doi: 10.1111/1755-0998.12428.

Smart, A.S., Tingley, R., Weeks, A.R., van Rooyen, A.R., and McCarthy, M.A. 2015. Environmental DNA sampling is more sensitive than a traditional survey technique for detecting an aquatic invader. Ecol. Appl. 25(7): 1944-1952.

Stuart, S., Chanson, J.S., Cox, N.A., Young, B.E., Rodrigues, A.S.L., Fishman, D.L., and Waller, R.W. 2004. Status and trends of amphibian declines and extinctions worldwide. Science 306: 1783-1786.

Taberlet, P., Coissac, E., Hajibabaei, M., and Rieseberg, L.H. 2012. Environmental DNA. Mol. Ecol. 21(8): 1789-1793. doi: 10.1111/J.1365-294x.2012.05542.X.

Takahara, T., Minamoto, T., Yamanaka, H., Doi, H., and Kawabata, Z. 2012. Estimation of fish biomass using environmental DNA. PLoS One 7(4): e35868. doi: 10.1371/journal.pone.0035868.

Tamura, K., and Nei, M. 1993. Estimation of the number of nucleotide substitutions in the control region of mitochondrial- DNA in humans and chimpanzees. Mol. Biol. Evol. 10: $512-526$.

Thomas, A.C., Deagle, B.E., Eveson, J.P., Harsch, C.H., and Trites, A.W. 2016. Quantitative DNA metabarcoding: improved estimates of species proportional biomass using correction factors derived from control material. Mol. Ecol. Resour. 16: 714-726. 
Thomsen, P.F., Kielgast, J., Iversen, L.L., Moller, P.R., Rasmussen, M., and Willerslev, E. 2012a. Detection of a diverse marine fish fauna using environmental DNA from seawater samples. PLoS One 7(8): e41732. doi: 10.1371/journal.pone.0041732.

Thomsen, P.F., Kielgast, J., Iversen, L.L., Wiuf, C., Rasmussen, M., Gilbert, M.T.P., Orlando, L., and Willerslev, E. 2012b. Monitoring endangered freshwater biodiversity using environmental DNA. Mol. Ecol. 21(11): 2565-2573. doi: 10.1111/J.1365294x.2011.05418.X.

Thomsen, P.F., and Willerslev, E. 2015. Environmental DNA - An emerging tool in conservation for monitoring past and present biodiversity. Biol. Conserv. 183: 4-18. doi: 10.1016/j.biocon.2014.11.019.

Tréguier, A., Paillisson, J.-M., Dejean, T., Valentini, A., Schlaepfer, M.A., and Roussel, J.-M. 2014. Environmental DNA surveillance for invertebrate species: advantages and technical limitations to detect invasive crayfish Procambarus clarkii in freshwater ponds. J. Appl. Ecol. 51: 871-879. doi: 10.1111/1365-2664.12262.

Turner, C.R., Barnes, M.A., Xu, C.C.Y., Jones, S.E., Jerde, C.L., and Lodge, D.M. 2014. Particle size distribution and optimal capture of aqueous macrobial eDNA. Methods Ecol. Evol. 5: 676-684. doi: 10.1111/2041-210X.12206.

Turner, C.R., Uy, L.K., and Everhart, R.C. 2015. Fish environmental DNA is more concentrated in aquatic sediments than surface water. Biol. Conserv. 183: 93-102. Untergasser, A., Cutcutache, I., Koressaar, T., Ye, J., Faircloth, B.C., Remm, M., and Rozen, S.G. 2012. Primer3-new capabilities and interfaces. Nucleic Acids Res. 40(15): e115. 
Valentini, A., Taberlet, P., Miaud, C., Civade, R., Herder, J., Thomsen, P.F., Bellemain, E., Besnard, A., Coissac, E., Boyer, F., Gaboriaud, C., Jean, P., Poulet, N., Roset, N., Copp, G.H., Geniez, P., Pont, D., Argillier, C., Baudoin, J.-M., Peroux, T., Crivelli, A.J., Olivier, A., Acqueberge, M., Le Brun, M., Rask Møller, P., Willerslev, E., and Dejean, T. 2015. Next-generation monitoring of aquatic biodiversity using environmental DNA metabarcoding. Mol. Ecol. doi: 10.1111/mec.13428.

Vences, M., Nagy, Z.T., Sonet, G., and Verheyen, E. 2012. DNA barcoding amphibians and reptiles. Methods Mol. Biol. 858: 79-107.doi: 10.1007/978-1-61779-591-6_5. Vences, M., Thomas, M., M. Bonett, R., and R. Vieites, D. 2005. Deciphering amphibian diversity through DNA barcoding: chances and challenges. Philos. Trans. R. Soc., B 360: 1859-1868. doi: 10.1098/rstb.2005.1717.

Wickham, H. 2009. ggplot2: elegant graphics for data analysis. Springer-Verlag New York.

Wilcox, T.M., McKelvey, K.S., Young, M.K., Jane, S.F., Lowe, W.H., Whiteley, A.R., and Schwartz, M.K. 2013. Robust detection of rare species using environmental DNA: the importance of primer specificity. PLoS One 8(3): e59520. doi: 10.1371/journal.pone.0059520.

Zylstra E.R., Steidl, R.J., and Swann, D.E. 2010. Evaluating survey methods for monitoring a rare vertebrate, the Sonoran desert tortoise. J. Wildl. Manage. 74: 13111318. 
Table 1. Occurrence index $(i)$ used to validate the eDNA metabarcoding dataset for each local amphibian and reptile species within each sampled location. For each species, the occurrence probability index is provided based on the species distribution range and the habitat preference based on atlas data and scientific literature respectively (see method for references).

\begin{tabular}{|l|l|l|}
\hline \multicolumn{1}{|c|}{ Occurrence index } & \multicolumn{1}{|c|}{ Distribution range } & \multicolumn{1}{|c|}{ Habitat preferences } \\
\hline 0 & Outside of the known distribution range of the species & - \\
\hline 1 & Within the species distribution range & $\begin{array}{l}\text { Terrestrial species (most snakes and the Eastern } \\
\text { red-backed salamanders (Plethodon cinereus)) }\end{array}$ \\
\hline 2 & Within the species distribution range & $\begin{array}{l}\text { Aquatic species (for at least one life stage) for } \\
\text { which the sampled habitat is not included in its } \\
\text { preferred habitat types. }\end{array}$ \\
\hline 3 & Within the species distribution range & $\begin{array}{l}\text { Aquatic species (for at least one life stage) for } \\
\text { which the sampled habitat is included in its } \\
\text { preferred habitat types. }\end{array}$ \\
\hline
\end{tabular}


Table 2. Primers and probe sequences used for qPCR analyses showing mismatches with closely-related reptile species that may occur in the sampling area covered in this study.

\begin{tabular}{|c|c|c|c|c|}
\hline Espèces & Noms latins & $\begin{array}{c}\text { F primer mismatches } \\
\left(5^{\prime}-3^{\prime}\right)\end{array}$ & $\begin{array}{c}\text { R primer mismatches } \\
\left(5^{\prime}-3^{\prime}\right)\end{array}$ & $\begin{array}{c}\text { Probe mismatches } \\
\left(5^{\prime}-3^{\prime}\right)\end{array}$ \\
\hline Wood turtle & Glyptemys insculpta & TGCCTCTGTAGACCTAACCATCTTT & AGTTGATAGCCCCTAAGATTGAAGATA & CTCTACACCTGGCCGGT \\
\hline Painted turtle & Chrysemys picta & 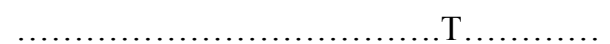 & 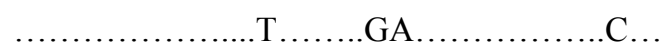 & ............. T..A.........G \\
\hline Common snapping turtle & Chelydra serpentina & $\ldots \ldots \ldots \ldots \mathrm{C} \ldots \ldots \ldots \ldots \mathrm{T} \ldots \mathrm{G} \ldots \ldots \mathrm{T} \ldots \mathrm{T} \ldots \mathrm{C}$ & , & ...С....Т....ТТ..А ........G \\
\hline Blanding's turtle & Emydoidea blandingii & (1, & 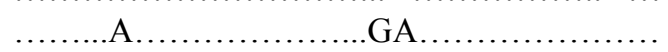 & ...С...С $\ldots \ldots \ldots \ldots . . . . . \ldots \ldots \ldots$ \\
\hline Northern watersnake & Nerodia sipedon & СC $\ldots \ldots \ldots$ A $\ldots$ G $\ldots \ldots \ldots \ldots$ GG $\ldots$ A $\ldots \ldots \ldots . .$. & . & ...С $\ldots \ldots \ldots . . . . \mathrm{Т} \ldots \ldots \mathrm{A} \ldots . . \mathrm{A}$ \\
\hline Common garter snake & Thamnophis sirtalis & CC ..........G........GG...A........ & 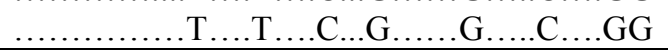 & 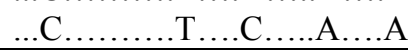 \\
\hline
\end{tabular}


Table 3. Group-species mitochondrial primers for amphibians and reptiles for eDNA metabarcoding analyses. Letters refer to the nucleic International Union of Pure and Applied Chemistry (IUPAC) codes. Species targeted within each group-species primer set are presented in Table S1.

\begin{tabular}{lllll}
\hline \multicolumn{1}{c}{ Group-species } & Gene & \multicolumn{1}{c}{ F primer (5'-3') } & \multicolumn{1}{c}{ R primer (5'-3') } & Total length (bp) \\
\hline Amphi_A & COI & GCiGGiGCYTCWGTAGA & iGGWGTTTGRTATTGiGAT & 132 \\
Amphi_B & Cytb & YCCATGAGGMCARATATCWTTT & ACKGARAAWCCiCCYCAAA & 111 \\
Amphi_C & COI & CMCTTYTiGGYGATGATCAAA & RGCTATATCAGGKGCTCCAA & 143 \\
Amphi_RANA & COI & TCWACYACACARTAYCAAACACC & CTCCTGCiGGGTCRAAAA & 151 \\
Reptile_TURTLE & COI & GCMGGiACMGGiTGAAC & GATATiGCiGGRGMTTTTAT & 167 \\
Reptile_SNAKE & COI & GCYGGYACiGGiTGAAC & TRAAGTTRATTGCYCCiAGGA & 130 \\
\hline
\end{tabular}


Table 4. Rivers sampled for the Wood Turtle semi-quantitative analyses, the relative abundance obtained by standardized visual surveys, the eDNA detection rates (i.e. total number of positive amplifications), the number of sites with positive amplifications, standard deviation $(S D)$ of eDNA among sites and relationship $\left(R^{2}\right)$ between the number of positive amplifications and the spatial ranking from downstream to upstream. For the latter, negative $R^{2}$ values depict lower number of eDNA detected downstream than upstream, whereas positive $R^{2}$ depict greater number of eDNA detected downstream than upstream.

\begin{tabular}{lccccc}
\hline River & $\begin{array}{c}\text { Relative } \\
\text { abundance }\end{array}$ & $\begin{array}{c}\text { Total number } \\
\text { of positive } \\
\text { amplifications }\end{array}$ & $\begin{array}{c}\text { Number of sites } \\
\text { with positive } \\
\text { amplifications }\end{array}$ & $S D$ & $\begin{array}{c}\text { Spatial distribution } \\
\text { effect }\left(R^{2}\right)\end{array}$ \\
\hline Mawcook & 0 & 0 & 0 & 0.00 & - \\
Quilliams & 1 & 8 & 3 & 1.87 & 0.03 \\
Yamaska & 2 & 22 & 7 & 2.49 & -0.02 \\
Jackson & 3 & 19 & 8 & 1.79 & 0.21 \\
Sutton & 5 & 32 & 10 & 1.81 & 0.01 \\
North Branch & 5 & 35 & 10 & 1.90 & 0.02 \\
Noire & 8 & 34 & 8 & 2.55 & -0.04 \\
Missisquoi & 18 & 47 & 9 & 2.21 & -0.19 \\
Renne & 18 & 47 & 9 & 2.11 & 0.08 \\
\hline
\end{tabular}


Table 5. Environmental DNA metabarcoding results including the number of amphibian and reptile species (i.e. species richness) and the number of reads for each species within each sampled location (i.e. lakes and rivers). For each occurrence index $(i)$, the proportions of species detections have been calculated for each location, whereas the proportions of location detections have been calculated for each species. Short horizontal lines depicts that no sequence has been found for this species whereas X shows that no amplification has been done for the species. Long horizontal lines showed that this species was not expected in any sampled locations for those particular species. Please refer to Figure 3 for Latin names. 


\begin{tabular}{|c|c|c|c|c|c|c|c|c|c|c|c|c|c|c|c|c|c|c|c|c|c|c|c|}
\hline & & \multirow[b]{2}{*}{ 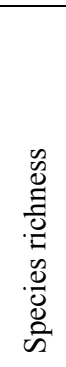 } & \multicolumn{4}{|c|}{ Proportion of species } & \multicolumn{12}{|c|}{ Amphibians } & \multicolumn{5}{|c|}{ Reptiles } \\
\hline & & & $\stackrel{m}{\|}$ & $\underset{\sim}{\stackrel{N}{\|}}$ & $\underset{\sim}{\|}$ & $\begin{array}{l}0 \\
\| \\
.\end{array}$ & 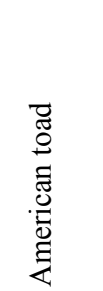 & 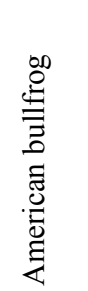 & 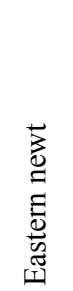 & 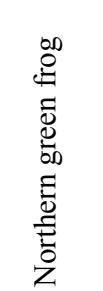 & 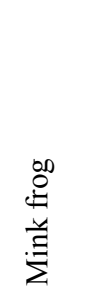 & 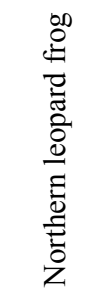 & 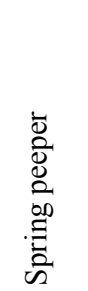 & 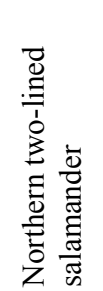 & 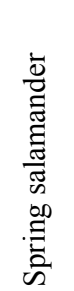 & 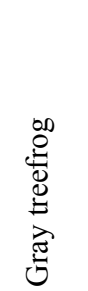 & $\begin{array}{l}00 \\
\stackrel{6}{0} \\
\stackrel{0}{0} \\
8 \\
3 \\
3\end{array}$ & 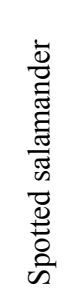 & 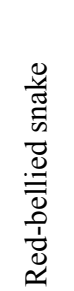 & 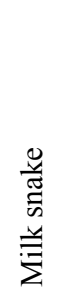 & 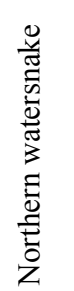 & 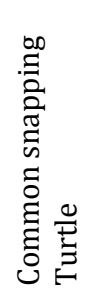 & 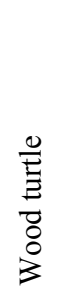 \\
\hline \multirow{7}{*}{ 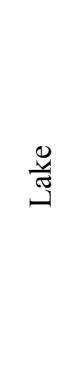 } & Aylmer & 4 & $3 / 8$ & $1 / 12$ & $0 / 5$ & $0 / 9$ & - & - & - & 2313 & 1118 & 1964 & 1116 & - & - & - & - & - & - & - & - & - & - \\
\hline & Baskatong & 4 & $3 / 9$ & $1 / 10$ & $0 / 5$ & $0 / 10$ & 1649 & 867 & - & 831 & 1878 & - & - & - & - & - & - & - & - & - & - & - & - \\
\hline & Joseph & 5 & $3 / 7$ & $1 / 10$ & $1 / 5$ & $0 / 11$ & 2165 & 1690 & - & 26 & - & 54 & - & - & - & - & - & - & 63 & - & - & - & - \\
\hline & Légaré & 1 & $1 / 7$ & $0 / 10$ & $0 / 5$ & $0 / 11$ & - & - & - & - & - & 15793 & - & - & - & - & - & - & - & - & - & - & - \\
\hline & Nominingue & 2 & $1 / 9$ & $1 / 10$ & $0 / 5$ & $0 / 10$ & - & 876 & - & - & - & - & 4032 & - & - & - & - & - & - & - & - & - & - \\
\hline & St-Jean & 1 & $1 / 7$ & $0 / 6$ & $0 / 3$ & $0 / 18$ & - & - & - & 1193 & - & - & - & - & - & - & - & - & - & - & - & - & - \\
\hline & à la Truite & 3 & $1 / 8$ & $2 / 10$ & $0 / 5$ & $0 / 10$ & - & - & - & 2577 & - & - & - & - & - & - & 460 & 421 & - & - & - & - & - \\
\hline \multirow{5}{*}{$\stackrel{\vec{\Delta}}{a}$} & North Branch & 10 & $7 / 12$ & $2 / 7$ & $1 / 6$ & $0 / 9$ & 6980 & 1116 & - & 37667 & - & 605 & - & 109 & 22 & 1570 & 26 & - & - & 186 & - & - & 12 \\
\hline & Renne & 5 & $4 / 10$ & $1 / 9$ & $0 / 6$ & $0 / 9$ & - & 9466 & 58 & 20888 & - & - & - & - & 43 & - & - & - & - & - & - & 5 & - \\
\hline & Yamaska & 9 & $7 / 13$ & $2 / 6$ & $0 / 6$ & $0 / 9$ & 104 & 484 & 55 & 33945 & - & 22 & 1541 & 58 & - & 974 & - & - & - & - & - & 28 & - \\
\hline & Jackson & 5 & $4 / 11$ & $1 / 4$ & $0 / 6$ & $0 / 9$ & $\mathrm{X}$ & 1102 & 8 & 30316 & - & - & $\mathrm{X}$ & 30 & - & $\mathrm{X}$ & 259 & - & - & - & - & - & - \\
\hline & Quilliams & 5 & $3 / 8$ & $1 / 4$ & $0 / 5$ & $1 / 7$ & 164 & 9039 & $\mathrm{X}$ & 51204 & - & - & - & 12 & $\mathrm{X}$ & - & - & $\mathrm{X}$ & - & - & 90 & - & - \\
\hline \multirow{3}{*}{ 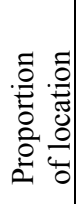 } & $i=3$ & & & & & & & & & & & & & & & & & & & & & & \\
\hline & $i=2$ & & & & & & $3 / 4$ & $8 / 12$ & $3 / 11$ & $10 / 12$ & $2 / 12$ & $5 / 12$ & - & $3 / 3$ & $1 / 3$ & - & - & - & $1 / 9$ & - & $0 / 2$ & $2 / 14$ & - \\
\hline & & & & & & & $2 / 7$ & - & - & - & - & - & $3 / 11$ & $1 / 9$ & $1 / 2$ & $2 / 10$ & $3 / 12$ & $1 / 11$ & - & - & - & - & - \\
\hline
\end{tabular}




\section{FIGURES}

Figure 1. Geographical locations of the sampled lakes in the Province of Québec (map A; Eastern Canada). Environmental DNA was collected in seven lakes (black triangles in map B) and nine section rivers (black dots in map C).

Figure 2. Relationship between percent eDNA detection rate and the $\log _{10}$ of the relative abundance obtained by standardized visual surveys of Wood turtle. The associated $95 \%$ confidence interval is depicted in dark gray.

Figure 3. Number of reads for each amphibian (upper graph) and reptile species (lower graph) within each body of water.

Figure 4. Data distribution of the number of reads for each species within each body of water for each occurrence index (see Table 1). The upper whisker extends from the hinge (i.e. the $75^{\text {th }}$ percentile) to the highest value that is within $1.5^{*} \mathrm{IQR}$ of the hinge, where $\mathrm{IQR}$ is the inter-quartile range. 


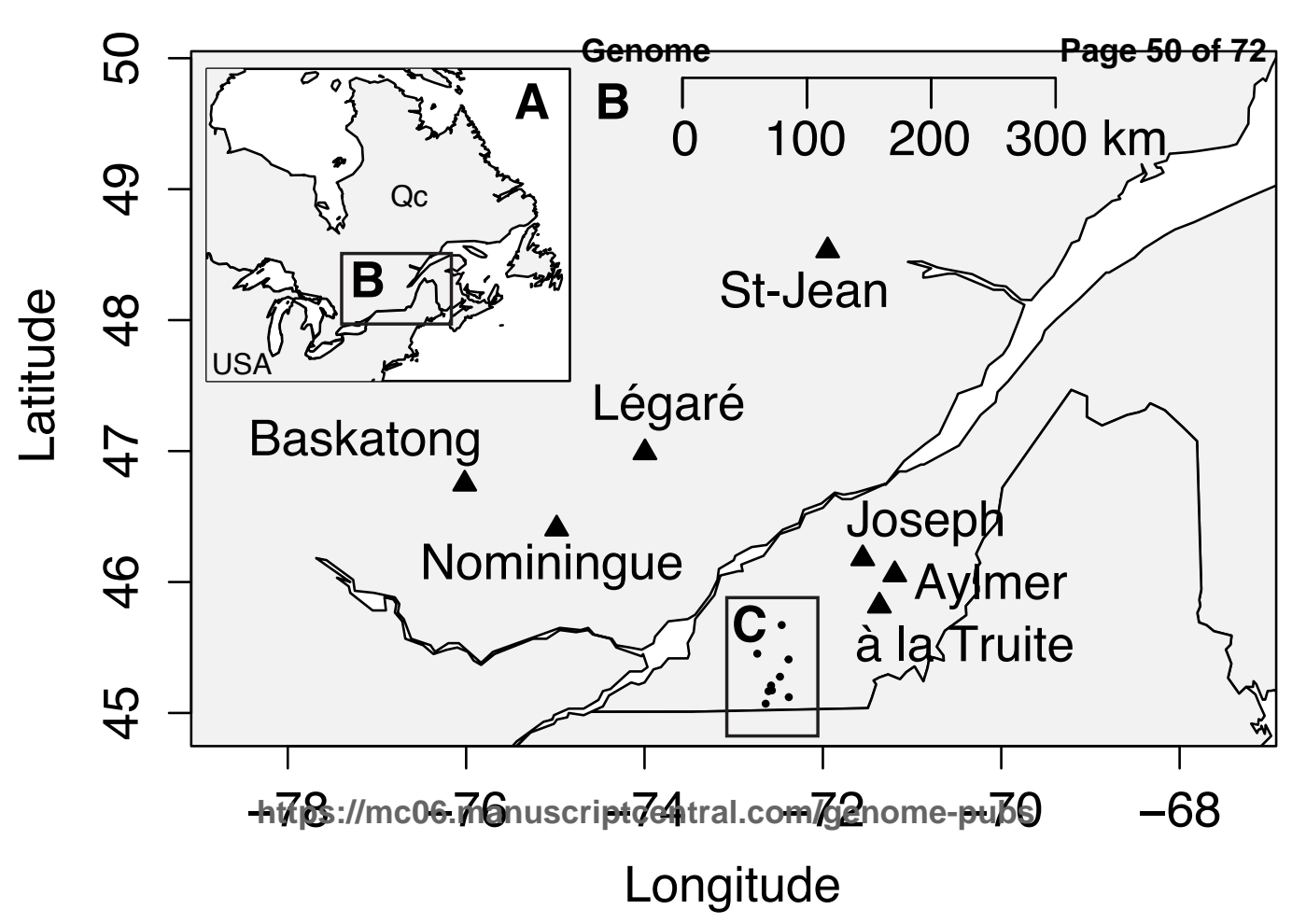




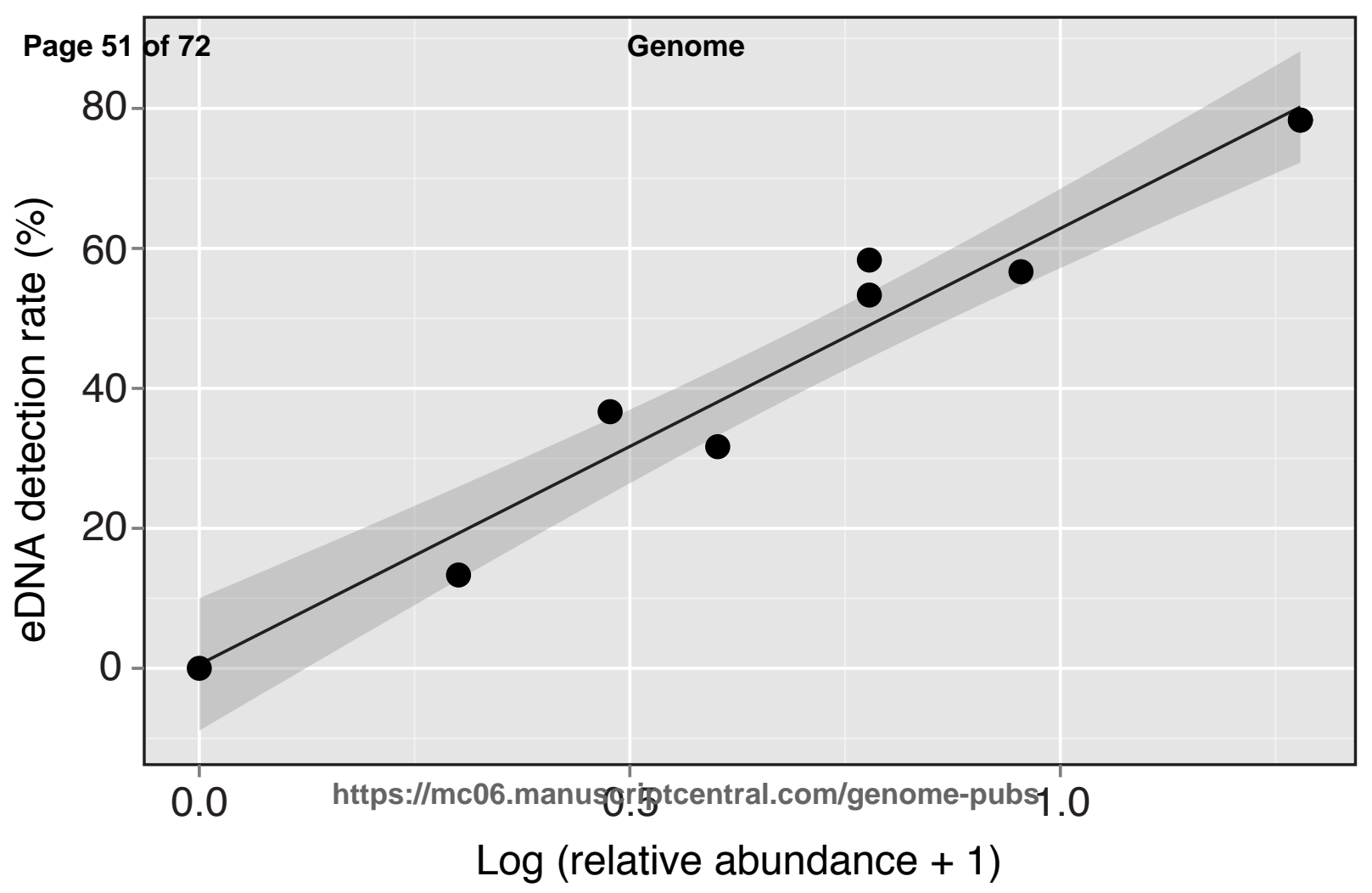




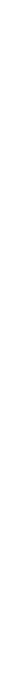




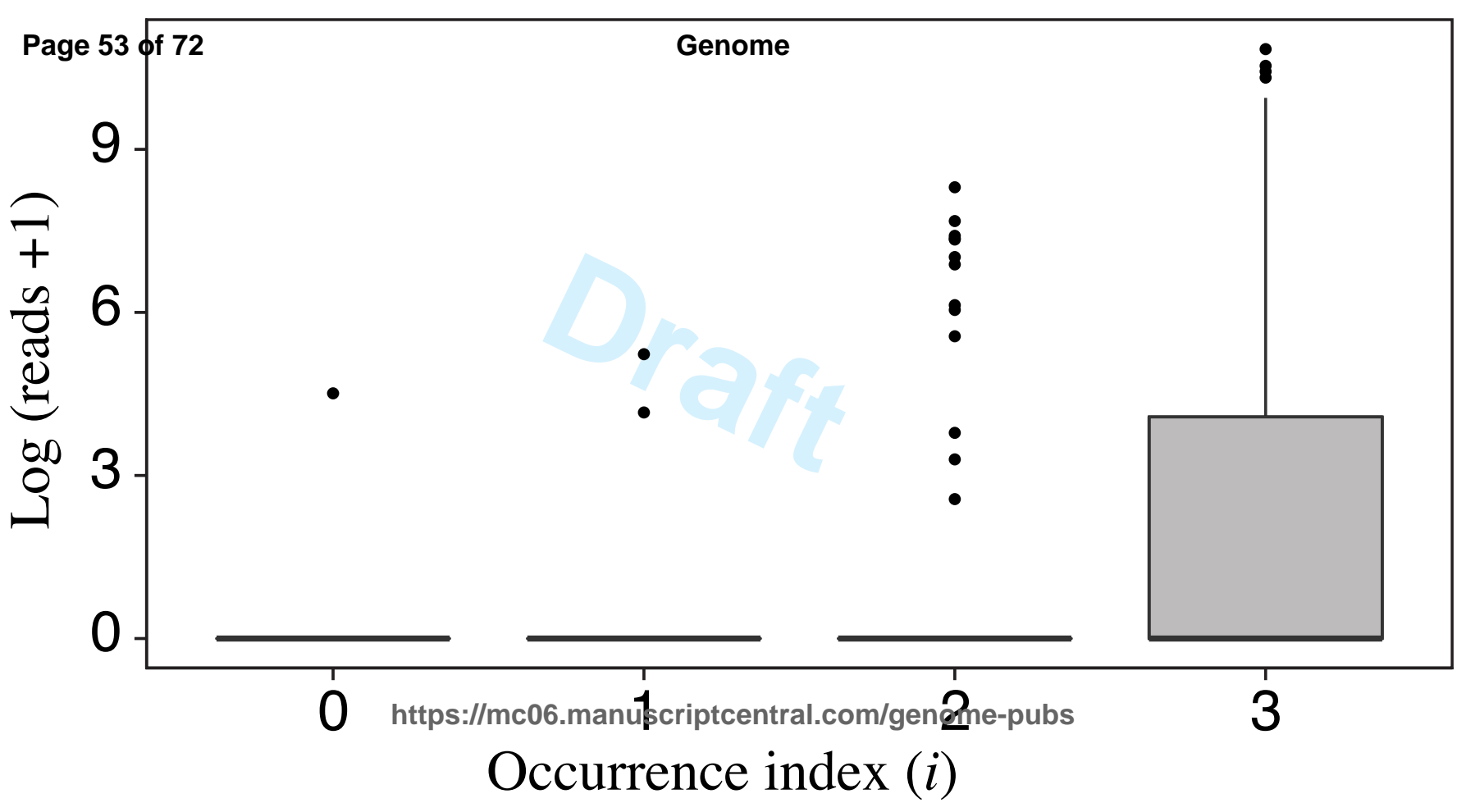


Table S1. Amphibians and reptiles used for the development of the primers (Table 1) and the occupancy model, primers targeting each species, species that primers have been tested in vitro ("X") and presence (1) and absence (0) of the sequences availability for the COI, cytb, 12S, 16S and 18S genes.

\begin{tabular}{|c|c|c|c|c|c|c|c|c|c|}
\hline \multirow[t]{9}{*}{$\overline{\text { Species group }}$} & Common name & Latin name & Primers & Tissue & COI & cytb & $12 S$ & $\mathbf{1 6 S}$ & $18 \mathrm{~S}$ \\
\hline & Mudpuppy & Necturus maculosus & Amphi_A & & 1 & 1 & 1 & 1 & 1 \\
\hline & Northern dusky & Desmognathus & & & & & & & \\
\hline & salamander & fuscus & Amphi_A & & 1 & 1 & 1 & 1 & 0 \\
\hline & $\begin{array}{l}\text { Allegheny mountain } \\
\text { dusky salamander }\end{array}$ & $\begin{array}{l}\text { Desmognathus } \\
\text { ochrophaeus }\end{array}$ & Amphi A & $X$ & 1 & 0 & 1 & 1 & 0 \\
\hline & Northern two-lined & & & & & & & & \\
\hline & salamander & Eurycea bislineata & Amphi_A & $\mathrm{X}$ & 1 & 1 & 1 & 1 & 0 \\
\hline & Sprıng salamander & $\begin{array}{l}\text { Gyrinophilus } \\
\text { porphyriticus }\end{array}$ & Amphi_A & $\mathrm{X}$ & 1 & 1 & 1 & 1 & 0 \\
\hline & Four-toed salamander & $\begin{array}{l}\text { Hemidactylium } \\
\text { scutatum }\end{array}$ & Amphi A & & 1 & 1 & 1 & 1 & 0 \\
\hline \multirow{10}{*}{ 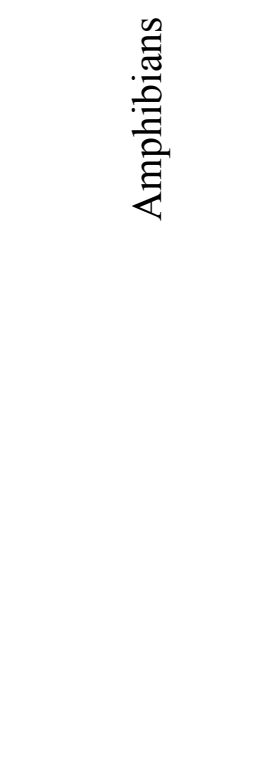 } & Eastern newt & Notophthalmus & & & & & & & \\
\hline & Blue-snotted & viridescens & Amphi_B & $\mathrm{X}$ & 1 & 1 & 1 & 1 & 1 \\
\hline & salamander & Ambystoma laterale & Amphi_B & $\mathrm{X}$ & 1 & 1 & 0 & 0 & 0 \\
\hline & Spotted salamander & $\begin{array}{l}\text { Ambystoma } \\
\text { maculatum }\end{array}$ & Amphi_B & $\mathrm{X}$ & 0 & 1 & 0 & 0 & 1 \\
\hline & $\begin{array}{l}\text { Eastern red-backed } \\
\text { salamander } \\
\text { American toad }\end{array}$ & $\begin{array}{l}\text { Plethodon cinereus } \\
\text { Anaxyrus (Bufo) }\end{array}$ & Amphi_B & $\mathrm{X}$ & 1 & 1 & 0 & 1 & 1 \\
\hline & & americanus & Amphi_C & $\mathrm{X}$ & 1 & 1 & 1 & 1 & 0 \\
\hline & Gray treefrog & Hyla versicolor & Amphi ${ }^{-} \mathrm{C}$ & & 1 & 1 & 1 & 1 & 1 \\
\hline & Spring peeper & Pseudacris crucifer & Amphi_C & $\mathrm{X}$ & 1 & 1 & 1 & 1 & 0 \\
\hline & Wood frog & $\begin{array}{l}\text { Lithobates (Rana) } \\
\text { sylvaticus }\end{array}$ & Amphi RANA & $X$ & 1 & 1 & 0 & 1 & 0 \\
\hline & Northern leopard frog & $\begin{array}{l}\text { Lithobates (Rana) } \\
\text { pipiens }\end{array}$ & Amphi RANA & X & 1 & 1 & 1 & 1 & 1 \\
\hline
\end{tabular}




\begin{tabular}{|c|c|c|c|c|c|c|c|c|c|}
\hline & Pickerel frog & $\begin{array}{l}\text { Lithobates (Rana) } \\
\text { palustris }\end{array}$ & Amphi_RANA & X & 0 & 0 & 1 & 1 & 0 \\
\hline & Northern green frog & Lithobates (Rana) & & & & & & & \\
\hline & Mink frog & $\begin{array}{l}\text { clamitans melanota } \\
\text { Lithobates (Rana) }\end{array}$ & Amphi_RANA & $\mathrm{X}$ & 1 & 1 & 1 & 1 & 1 \\
\hline & 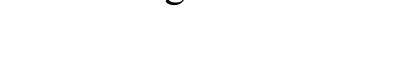 & septentrionalis & Amphi_RANA & $X$ & 1 & 1 & 1 & 1 & 0 \\
\hline & American bullfrog & $\begin{array}{l}\text { Lithobates (Rana) } \\
\text { catesbeianus }\end{array}$ & Amphi_RANA & & 1 & 1 & 1 & 1 & 0 \\
\hline & Snapping turtle & Chelydra serpentina & Reptile_TURTLE & $\mathrm{X}$ & 1 & 1 & 1 & 1 & 1 \\
\hline & Eastern musk turtle & Sternotherus & Reptile_TURTLE & & & & & & \\
\hline & & odoratus & & $X$ & 1 & 1 & 1 & 1 & 0 \\
\hline$\approx$ & Painted turtle & Chrysemys picta & Reptile_TURTLE & $X$ & 1 & 1 & 1 & 1 & 0 \\
\hline 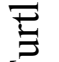 & Northern map turtle & Graptemys & Reptile_TURTLE & & & & & & \\
\hline & Blanding's turtle & $\begin{array}{l}\text { geographica } \\
\text { Emvdoidea }\end{array}$ & Reptile TURTLE & $X$ & 1 & 1 & 0 & 0 & 0 \\
\hline & & blandingii & & $\mathrm{X}$ & 1 & 1 & 0 & 0 & 0 \\
\hline & Wood turtle & Glyptemys insculpta & Reptile_TURTLE & $X$ & 1 & 1 & 1 & 0 & 0 \\
\hline & Spiny softshell & Apalone spinifera & Reptile_TURTLE & $X$ & 1 & 1 & 1 & 1 & 1 \\
\hline & Common gartersnake & Thamnophis sirtalis & Reptile_SNAKE & X & 1 & 1 & 1 & 1 & 0 \\
\hline & Northern ribbonsnake & Thamnophis sauritus & Reptile_SNAKE & & & & & & \\
\hline & & septentrionalis & & $X$ & 1 & 1 & 0 & 1 & 0 \\
\hline & Northern watersnake & Nerodia sipedon & Reptile_SNAKE & X & 1 & 1 & 1 & 0 & 0 \\
\hline d & Red-bellied snake & Storeria & Reptile_SNAKE & & & & & & \\
\hline 气 & & occipitomaculata & & X & 1 & 1 & 1 & 0 & 0 \\
\hline & Dekay’s brownsnake & Storeria dekayi & Reptile_SNAKE & X & 1 & 1 & 1 & 1 & 0 \\
\hline & Smooth greensnake & Opheodrys vernalis & Reptile_SNAKE & $\mathrm{X}$ & 1 & 0 & 0 & 0 & 0 \\
\hline & Ring-necked snake & Diadophis punctatus & Reptile_SNAKE & $X$ & 0 & 1 & 1 & 1 & 0 \\
\hline & Milksnake & Lampropeltis & Reptile_SNAKE & & & & & & \\
\hline & & triangulum & & $\mathrm{X}$ & 1 & 1 & 1 & 0 & 1 \\
\hline
\end{tabular}


Table S2. Locations of sampling site, date of the sampling, delay between sampling and filtration, type of analyses (eDNA metabarcoding and qPCR) and number of positive qPCR amplifications of Wood turtle. In accordance with the recommendation of the Committee on the Status of Endangered Wildlife in Canada (COSEWIC), the exact location were not provided for the wood turtles sampling sites to avoid illegal collection risk.

\begin{tabular}{|c|c|c|c|c|c|c|c|c|}
\hline $\begin{array}{l}\text { Location } \\
\text { type }\end{array}$ & Location names & No sample & Latitude & Longitude & $\begin{array}{c}\text { eDNA } \\
\text { sampling } \\
\text { date }\end{array}$ & $\begin{array}{c}\text { Delay } \\
\text { sampling- } \\
\text { filtration }\end{array}$ & Type analyses & $\begin{array}{c}\text { Nb } \\
\text { amplification }\end{array}$ \\
\hline River & Renne & 2 & - & - & $2013-07-23$ & $10: 54$ & Metabarcoding / qPCR & 6 \\
\hline River & Renne & 3 & - & - & $2013-07-23$ & $10: 37$ & Metabarcoding / qPCR & 6 \\
\hline River & Renne & 4 & - & - & $2013-07-23$ & $10: 52$ & qPCR & 2 \\
\hline River & Renne & 5 & - & - & $2013-07-23$ & $10: 42$ & Metabarcoding / qPCR & 6 \\
\hline River & Renne & 1 & - & - & $2013-07-23$ & $11: 25$ & qPCR & 6 \\
\hline River & Renne & 6 & - & - & $2013-07-23$ & $12: 05$ & Metabarcoding / qPCR & 5 \\
\hline River & Renne & 7 & - & - & $2013-07-23$ & $11: 58$ & Metabarcoding / qPCR & 6 \\
\hline River & Renne & 8 & - & - & $2013-07-23$ & $11: 45$ & qPCR & 6 \\
\hline River & Renne & 9 & - & — & $2013-07-23$ & $12: 05$ & Metabarcoding / qPCR & 0 \\
\hline River & Renne & 10 & - & - & $2013-07-23$ & $10: 55$ & Metabarcoding / qPCR & 4 \\
\hline River & Noire & 1 & - & - & $2013-07-23$ & $9: 44$ & qPCR & 0 \\
\hline River & Noire & 3 & - & - & $2013-07-23$ & $10: 04$ & qPCR & 6 \\
\hline River & Noire & 5 & - & - & $2013-07-23$ & $10: 16$ & qPCR & 6 \\
\hline River & Noire & 7 & - & - & $2013-07-23$ & $10: 11$ & qPCR & 3 \\
\hline River & Noire & 9 & - & - & $2013-07-23$ & $10: 20$ & qPCR & 4 \\
\hline River & Noire & 2 & - & - & $2013-07-23$ & $9: 45$ & qPCR & 2 \\
\hline River & Noire & 4 & - & - & $2013-07-23$ & $10: 00$ & qPCR & 6 \\
\hline River & Noire & 6 & - & - & $2013-07-23$ & $10: 20$ & qPCR & 0 \\
\hline River & Noire & 8 & - & - & $2013-07-23$ & $10: 05$ & qPCR & 1 \\
\hline River & Noire & 10 & - & - & $2013-07-23$ & $10: 15$ & qPCR & 6 \\
\hline River & Mawcook & 1 & - & - & $2013-07-23$ & $16: 22$ & qPCR & 0 \\
\hline River & Mawcook & 2 & - & - & $2013-07-23$ & $16: 41$ & qPCR & 0 \\
\hline
\end{tabular}




$\begin{array}{ll}\text { River } & \text { Mawcook } \\ \text { River } & \text { Mawcook } \\ \text { River } & \text { Mawcook } \\ \text { River } & \text { Mawcook } \\ \text { River } & \text { Mawcook } \\ \text { River } & \text { Mawcook } \\ \text { River } & \text { Mawcook } \\ \text { River } & \text { Mawcook } \\ \text { River } & \text { North Branch } \\ \text { River } & \text { North Branch } \\ \text { River } & \text { North Branch } \\ \text { River } & \text { North Branch } \\ \text { River } & \text { North Branch } \\ \text { River } & \text { North Branch } \\ \text { River } & \text { North Branch } \\ \text { River } & \text { North Branch } \\ \text { River } & \text { North Branch } \\ \text { River } & \text { North Branch } \\ \text { River } & \text { Jackson } \\ \text { River } & \text { Jackson } \\ \text { River } & \text { Jackson } \\ \text { River } & \text { Jackson } \\ \text { River } & \text { Jackson } \\ \text { River } & \text { Jackson } \\ \text { River } & \text { Jackson } \\ \text { River } & \text { Jackson } \\ \text { River } & \text { Jackson } \\ \text { River } & \text { Jackson } \\ \text { River } & \text { Yamaska } \\ \text { River } & \text { Yamaska } \\ & \end{array}$

$\begin{array}{rlll}3 & - & - & 2013-07-23 \\ 4 & - & - & 2013-07-23 \\ 5 & - & - & 2013-07-23 \\ 6 & - & - & 2013-07-23 \\ 7 & - & - & 2013-07-23 \\ 8 & - & - & 2013-07-23 \\ 9 & - & - & 2013-07-23 \\ 10 & - & - & 2013-07-23 \\ 1 & - & - & 2013-07-24 \\ 2 & - & - & 2013-07-24 \\ 3 & - & - & 2013-07-24 \\ 4 & - & - & 2013-07-24 \\ 5 & - & - & 2013-07-24 \\ 6 & - & - & 2013-07-24 \\ 7 & - & - & 2013-07-24 \\ 8 & - & - & 2013-07-24 \\ 9 & - & - & 2013-07-24 \\ 10 & - & - & 2013-07-24 \\ 1 & - & - & 2013-07-24 \\ 2 & - & - & 2013-07-24 \\ 3 & - & - & 2013-07-24 \\ 4 & - & - & 2013-07-24 \\ 5 & - & - & 2013-07-24 \\ 6 & - & - & 2013-07-24 \\ 7 & - & - & 2013-07-24 \\ 8 & - & - & 2013-07-24 \\ 9 & - & 2013-07-24 \\ 10 & - & 2013-07-24 \\ 2 & - & 2013-07-24 \\ 1 & - & 2013-07-24\end{array}$

\begin{tabular}{|c|c|}
\hline $16: 34$ & qPCR \\
\hline $16: 26$ & qPCR \\
\hline 23:04 & qPCR \\
\hline $5: 25$ & qPCR \\
\hline $15: 35$ & qPCR \\
\hline $15: 43$ & qPCR \\
\hline $16: 20$ & qPCR \\
\hline $16: 30$ & qPCR \\
\hline $9: 50$ & qPCR \\
\hline $9: 40$ & Metabarcoding / qPCR \\
\hline $9: 30$ & Metabarcoding / qPCR \\
\hline $9: 45$ & qPCR \\
\hline $9: 40$ & Metabarcoding / qPCR \\
\hline $10: 10$ & qPCR \\
\hline $10: 30$ & Metabarcoding / qPCR \\
\hline $10: 20$ & Metabarcoding / qPCR \\
\hline $10: 10$ & Metabarcoding / qPCR \\
\hline $11: 34$ & Metabarcoding / qPCR \\
\hline $5: 19$ & qPCR \\
\hline $5: 41$ & Metabarcoding / qPCR \\
\hline $5: 34$ & Metabarcoding / qPCR \\
\hline $5: 26$ & qPCR \\
\hline $5: 46$ & Metabarcoding / qPCR \\
\hline $5: 47$ & qPCR \\
\hline $5: 45$ & Metabarcoding / qPCR \\
\hline $6: 20$ & Metabarcoding / qPCR \\
\hline $6: 25$ & Metabarcoding / qPCR \\
\hline $6: 35$ & Metabarcoding / qPCR \\
\hline $2: 55$ & Metabarcoding / qPCR \\
\hline $2: 46$ & Metabarcoding / qPCR \\
\hline
\end{tabular}

0

0

$$
0
$$$$
0
$$$$
0
$$$$
0
$$$$
0
$$$$
\begin{aligned}
& 1 \\
& 4
\end{aligned}
$$$$
\begin{aligned}
& 4 \\
& 5
\end{aligned}
$$$$
5
$$$$
\begin{aligned}
& 1 \\
& 5
\end{aligned}
$$$$
1
$$$$
4
$$$$
6
$$$$
5
$$$$
3
$$$$
\begin{aligned}
& 3 \\
& 3
\end{aligned}
$$$$
3
$$$$
3
$$$$
6
$$$$
2
$$$$
\begin{aligned}
& 0 \\
& 2
\end{aligned}
$$$$
2
$$$$
1
$$$$
0
$$$$
1
$$$$
1
$$

https://mc06.manuscriptcentral.com/genome-pubs 


$\begin{array}{ll}\text { River } & \text { Yamaska } \\ \text { River } & \text { Yamaska } \\ \text { River } & \text { Yamaska } \\ \text { River } & \text { Yamaska } \\ \text { River } & \text { Yamaska } \\ \text { River } & \text { Yamaska } \\ \text { River } & \text { Yamaska } \\ \text { River } & \text { Yamaska } \\ \text { River } & \text { Quilliams } \\ \text { River } & \text { Quilliams } \\ \text { River } & \text { Quilliams } \\ \text { River } & \text { Quilliams } \\ \text { River } & \text { Quilliams } \\ \text { River } & \text { Quilliams } \\ \text { River } & \text { Quilliams } \\ \text { River } & \text { Quilliams } \\ \text { River } & \text { Quilliams } \\ \text { River } & \text { Quilliams } \\ \text { River } & \text { Sutton } \\ \text { River } & \text { Sutton } \\ \text { River } & \text { Sutton } \\ \text { River } & \text { Sutton } \\ \text { River } & \text { Sutton } \\ \text { River } & \text { Sutton } \\ \text { River } & \text { Sutton } \\ \text { River } & \text { Sutton } \\ \text { River } & \text { Sutton } \\ \text { River } & \text { Sutton } \\ \text { River } & \text { Missisquoi Nord } \\ \text { River } & \text { Missisquoi Nord } \\ & \end{array}$

\begin{tabular}{|c|c|c|c|c|}
\hline 3 & - & - & $2013-07-24$ & $2: 39$ \\
\hline 4 & - & - & $2013-07-24$ & $2: 53$ \\
\hline 5 & - & - & $2013-07-24$ & $2: 45$ \\
\hline 6 & - & 一 & $2013-07-24$ & $2: 00$ \\
\hline 7 & - & 一 & $2013-07-24$ & $1: 45$ \\
\hline 8 & - & - & $2013-07-24$ & $2: 10$ \\
\hline 9 & - & - & $2013-07-24$ & $2: 00$ \\
\hline 10 & - & - & $2013-07-24$ & $1: 50$ \\
\hline 1 & - & - & $2013-07-24$ & $5: 25$ \\
\hline 2 & - & - & $2013-07-24$ & $5: 15$ \\
\hline 3 & 一 & - & $2013-07-24$ & $5: 35$ \\
\hline 4 & - & - & $2013-07-24$ & $5: 20$ \\
\hline 5 & - & - & $2013-07-24$ & $7: 05$ \\
\hline 6 & - & - & $2013-07-24$ & $6: 50$ \\
\hline 7 & - & - & $2013-07-24$ & $7: 00$ \\
\hline 8 & - & - & $2013-07-24$ & $7: 30$ \\
\hline 9 & - & - & $2013-07-24$ & $7: 40$ \\
\hline 10 & - & - & $2013-07-24$ & $7: 50$ \\
\hline 1 & - & - & $2013-07-25$ & $10: 05$ \\
\hline 2 & - & - & $2013-07-25$ & $9: 25$ \\
\hline 3 & - & - & $2013-07-25$ & $9: 35$ \\
\hline 4 & - & - & $2013-07-25$ & $10: 30$ \\
\hline 5 & - & - & $2013-07-25$ & $10: 15$ \\
\hline 6 & - & 一 & $2013-07-25$ & $8: 55$ \\
\hline 7 & - & - & $2013-07-25$ & $9: 25$ \\
\hline 8 & - & - & $2013-07-25$ & $9: 35$ \\
\hline 9 & - & - & $2013-07-25$ & $9: 30$ \\
\hline 10 & - & - & $2013-07-25$ & $9: 20$ \\
\hline 1 & - & - & $2013-07-25$ & $6: 25$ \\
\hline 2 & - & - & $2013-07-25$ & $6: 50$ \\
\hline
\end{tabular}

qPCR
Metabarcoding / qPCR

Metabarcoding / qPCR

Metabarcoding / qPCR

Metabarcoding / qPCR

$$
\text { qPCR }
$$

Metabarcoding / qPCR qPCR qPCR

Metabarcoding / qPCR

Metabarcoding / qPCR

Metabarcoding / qPCR

Metabarcoding / qPCR

Metabarcoding / qPCR

qPCR

Metabarcoding / qPCR

Metabarcoding / qPCR

qPCR

qPCR

qPCR

qPCR

qPCR

qPCR

qPCR

qPCR

qPCR

qPCR

qPCR

qPCR

qPCR 


$\begin{array}{ll}\text { River } & \text { Missisquoi Nord } \\ \text { River } & \text { Missisquoi Nord } \\ \text { River } & \text { Missisquoi Nord } \\ \text { River } & \text { Missisquoi Nord } \\ \text { River } & \text { Missisquoi Nord } \\ \text { River } & \text { Missisquoi Nord } \\ \text { River } & \text { Missisquoi Nord } \\ \text { River } & \text { Missisquoi Nord } \\ \text { Lake } & \text { à la truite } \\ \text { Lake } & \text { à la truite } \\ \text { Lake } & \text { à la truite } \\ \text { Lake } & \text { à la truite } \\ \text { Lake } & \text { à la truite } \\ \text { Lake } & \text { à la truite } \\ \text { Lake } & \text { à la truite } \\ \text { Lake } & \text { St-Jean } \\ \text { Lake } & \text { St-Jean } \\ \text { Lake } & \text { St-Jean } \\ \text { Lake } & \text { St-Jean } \\ \text { Lake } & \text { St-Jean } \\ \text { Lake } & \text { St-Jean } \\ \text { Lake } & \text { St-Jean } \\ \text { Lake } & \text { Joseph } \\ \text { Lake } & \text { Joseph } \\ \text { Lake } & \text { Joseph } \\ \text { Lake } & \text { Joseph } \\ \text { Lake } & \text { Joseph } \\ \text { Lake } & \text { Joseph } \\ \text { Lake } & \text { Joseph } \\ \text { Lake } & \text { Légaré } \\ & \end{array}$

$\begin{array}{rrrrr}3 & - & - & 2013-07-25 & 7: 00 \\ 4 & - & - & 2013-07-25 & 8: 05 \\ 5 & - & - & 2013-07-25 & 8: 20 \\ 6 & - & - & 2013-07-25 & 8: 10 \\ 7 & - & - & 2013-07-25 & 8: 00 \\ 8 & - & - & 2013-07-25 & 8: 15 \\ 9 & - & - & 2013-07-25 & 9: 30 \\ 10 & - & - & 2013-07-25 & 9: 20 \\ 1 & 46.05688 & -71.19396 & 2013-05-14 & 3: 40 \\ 2 & 46.05326 & -71.19412 & 2013-05-14 & 3: 05 \\ 3 & 46.04903 & -71.19489 & 2013-05-14 & 3: 23 \\ 4 & 46.04553 & -71.18156 & 2013-05-14 & 2: 12 \\ 5 & 46.04821 & -71.20242 & 2013-05-14 & 3: 26 \\ 6 & 46.04657 & -71.20107 & 2013-05-14 & 3: 09 \\ 10 & 46.04513 & -71.17673 & 2013-05-14 & 2: 43 \\ 2 & 48.57298 & 72.03938 & 2013-05-15 & 6: 30 \\ 3 & 48.59618 & 71.88017 & 2013-05-15 & 3: 22 \\ 4 & 48.62485 & 71.83031 & 2013-05-15 & 2: 55 \\ 5 & 48.63808 & 71.98399 & 2013-05-15 & 3: 27 \\ 6 & 48.64525 & 72.07522 & 2013-05-15 & 3: 00 \\ 7 & 48.44143 & 71.71327 & 2013-05-15 & 4: 25 \\ 8 & 48.47427 & 72.01611 & 2013-05-15 & 4: 55 \\ 2 & 46.19522 & 71.55649 & 2013-05-14 & 23: 40 \\ 3 & 46.19997 & 71.55503 & 2013-05-14 & 23: 27 \\ 4 & 46.20158 & 71.55325 & 2013-05-14 & 23: 18 \\ 6 & 46.21615 & 71.52598 & 2013-05-14 & 23: 54 \\ 7 & 46.21261 & 71.53568 & 2013-05-14 & 22: 30 \\ 8 & 46.18900 & 71.55647 & 2013-05-14 & 23: 50 \\ 9 & 46.21440 & 71.53096 & 2013-05-14 & 22: 20 \\ 2 & 46.97369 & -73.94930 & 2013-05-21 & 23: 48\end{array}$

$$
\begin{aligned}
& \text { qPCR } \\
& \text { qPCR } \\
& \text { qPCR } \\
& \text { qPCR } \\
& \text { qPCR } \\
& \text { qPCR } \\
& \text { qPCR } \\
& \text { qPCR }
\end{aligned}
$$

Metabarcoding Metabarcoding Metabarcoding Metabarcoding Metabarcoding Metabarcoding Metabarcoding Metabarcoding Metabarcoding Metabarcoding Metabarcoding Metabarcoding Metabarcoding Metabarcoding Metabarcoding Metabarcoding Metabarcoding Metabarcoding Metabarcoding Metabarcoding Metabarcoding Metabarcoding 


\begin{tabular}{|c|c|c|c|c|c|c|c|}
\hline Lake & Légaré & 4 & 46.94569 & -73.95886 & 2013-05-21 & 23:29 & Metabarcoding \\
\hline Lake & Légaré & 5 & 46.95379 & -73.96066 & $2013-05-21$ & $23: 23$ & Metabarcoding \\
\hline Lake & Légaré & 6 & 46.95314 & -73.96453 & $2013-05-21$ & $23: 18$ & Metabarcoding \\
\hline Lake & Légaré & 7 & 46.95582 & -73.97406 & 2013-05-21 & $23: 11$ & Metabarcoding \\
\hline Lake & Légaré & 9 & 46.97801 & -73.97927 & $2013-05-21$ & $22: 54$ & Metabarcoding \\
\hline Lake & Légaré & 10 & 46.98874 & -73.99514 & 2013-05-21 & $22: 47$ & Metabarcoding \\
\hline Lake & Aylmer & 3 & 45.81129 & 71.38858 & $2013-05-23$ & $5: 16$ & Metabarcoding \\
\hline Lake & Aylmer & 4 & 45.77929 & 71.37277 & $2013-05-23$ & $5: 23$ & Metabarcoding \\
\hline Lake & Aylmer & 5 & 45.79633 & 71.35501 & $2013-05-23$ & $5: 15$ & Metabarcoding \\
\hline Lake & Aylmer & 6 & 45.79956 & 71.35127 & $2013-05-23$ & $5: 12$ & Metabarcoding \\
\hline Lake & Aylmer & 7 & 45.81233 & 71.33366 & $2013-05-23$ & $5: 21$ & Metabarcoding \\
\hline Lake & Aylmer & 8 & 45.83416 & 71.33845 & $2013-05-23$ & $5: 15$ & Metabarcoding \\
\hline Lake & Aylmer & 9 & 45.80266 & 71.35494 & $2013-05-23$ & $5: 08$ & Metabarcoding \\
\hline Lake & Nominingue & 1 & 46.45723 & 74.95111 & $2013-05-23$ & $19: 30$ & Metabarcoding \\
\hline Lake & Nominingue & 2 & 46.44168 & 74.98167 & $2013-05-23$ & $19: 10$ & Metabarcoding \\
\hline Lake & Nominingue & 3 & 46.43529 & 74.96722 & $2013-05-23$ & $19: 05$ & Metabarcoding \\
\hline Lake & Nominingue & 4 & 46.43029 & 74.96861 & $2013-05-23$ & $20: 55$ & Metabarcoding \\
\hline Lake & Nominingue & 7 & 46.42307 & 74.96278 & $2013-05-23$ & $20: 55$ & Metabarcoding \\
\hline Lake & Nominingue & 8 & 46.41917 & 74.98083 & $2013-05-23$ & $20: 45$ & Metabarcoding \\
\hline Lake & Nominingue & 10 & 46.40640 & 74.98500 & $2013-05-23$ & $20: 45$ & Metabarcoding \\
\hline Lake & Baskatong & 1 & 46.74933 & 76.01614 & $2013-05-23$ & $6: 50$ & Metabarcoding \\
\hline Lake & Baskatong & 2 & 46.89473 & 75.79413 & $2013-05-23$ & $6: 20$ & Metabarcoding \\
\hline Lake & Baskatong & 3 & 46.95040 & 75.76459 & $2013-05-23$ & $6: 05$ & Metabarcoding \\
\hline Lake & Baskatong & 4 & 46.81906 & 75.84227 & $2013-05-23$ & $5: 54$ & Metabarcoding \\
\hline Lake & Baskatong & 7 & 46.77589 & 75.73256 & $2013-05-23$ & $5: 38$ & Metabarcoding \\
\hline Lake & Baskatong & 8 & 46.71459 & 75.78047 & $2013-05-23$ & $5: 17$ & Metabarcoding \\
\hline Lake & Baskatong & 9 & 46.73327 & 75.82419 & $2013-05-23$ & $5: 08$ & Metabarcoding \\
\hline
\end{tabular}


Table S3. Library details including the concentration $(\mathrm{ng} / \mu \mathrm{L})$ of the purified final PCR products measured by PicoGreen (ng/ $\mu \mathrm{L})$ and the final PCR volume mixed $(\mu \mathrm{L})$ for each primer (columns) and locations separately (rows).

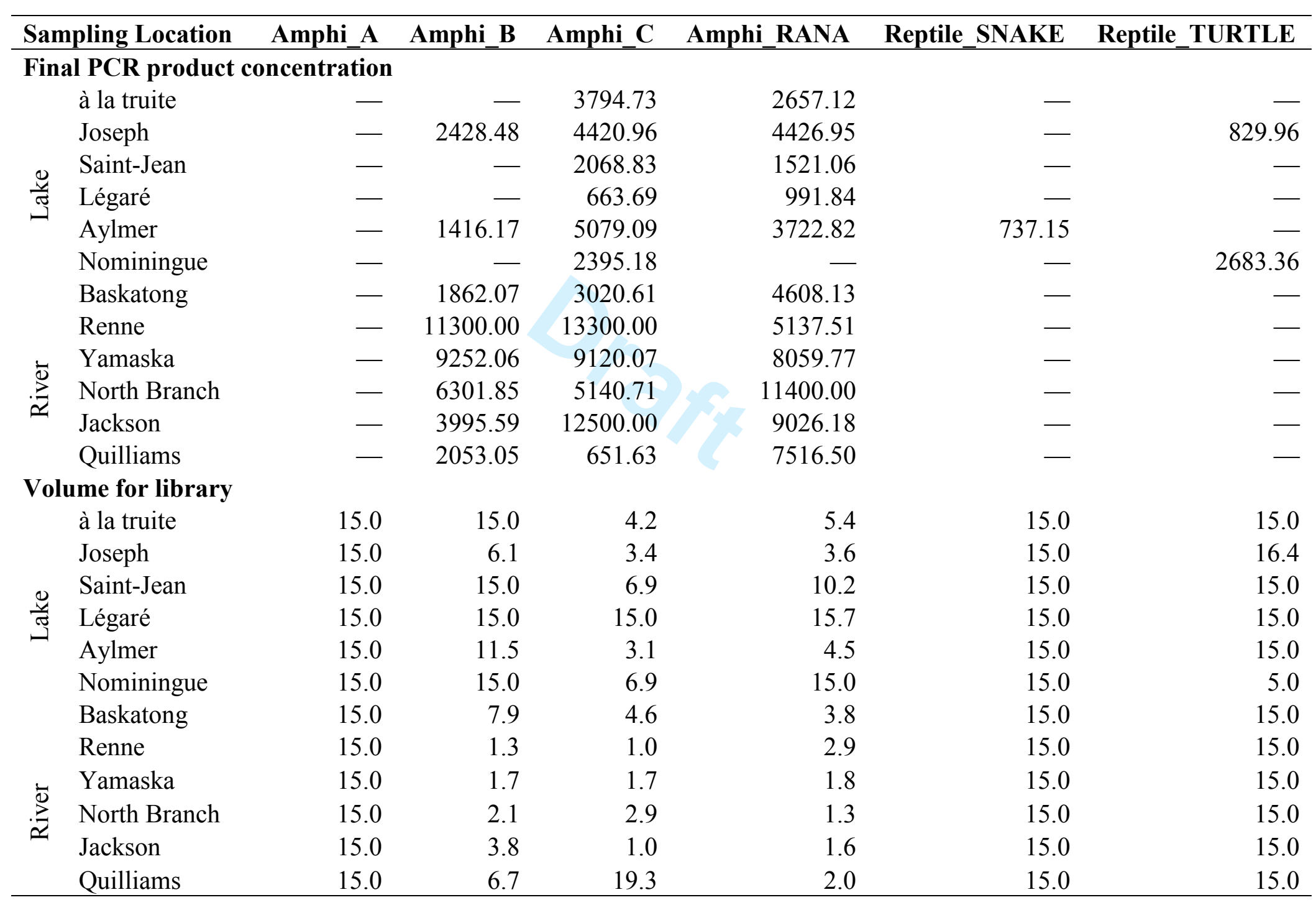


Table S4. Count of sequences for each data analyses steps (i.e. pipeline) for each library (i.e. SRA accession number: SRX accession for each primer pairs) including the number of raw reads for the forward side (i.e. count from the de-multiplexing), the number of reads without ambiguous nucleotides, sequences remaining within the expected amplicon length ( $\pm 5 \mathrm{bp})$ and the sequences remaining with successful BLAST results ( $\geq 94 \%$ similarity).

\begin{tabular}{|c|c|c|c|c|c|}
\hline Sampling location & Primer & $\begin{array}{c}\text { SRA accession } \\
\text { number }\end{array}$ & $\begin{array}{l}\text { Number of raw } \\
\text { reads }\end{array}$ & $\begin{array}{l}\text { Sequences } \\
\text { remaining with } \\
\text { expected length } \\
\text { and without } \\
\text { ambiguous } \\
\text { nucleotides }\end{array}$ & $\begin{array}{l}\text { Sequences } \\
\text { with } \\
\text { successful } \\
\text { blast }\end{array}$ \\
\hline \multirow[t]{6}{*}{ à la truite } & Amphi_A & SRX1615129 & 12 & 3 & 0 \\
\hline & Amphi_B & SRX1615130 & 18155 & 14537 & 421 \\
\hline & Amphi_C & SRX1615127 & 22131 & 8694 & 0 \\
\hline & Amphi_RANA & SRX1615128 & 27456 & 3499 & 3038 \\
\hline & Reptile_SNAKE & SRX1615126 & 387 & 95 & 0 \\
\hline & Reptile_TURTLE & SRX1615131 & 1203 & 7 & 1 \\
\hline \multirow[t]{6}{*}{ Joseph } & Amphi_A & SRX1615786 & 16 & 1 & 0 \\
\hline & Amphi_B & SRX1615788 & 85332 & 79145 & 1 \\
\hline & Amphi-C & SRX1615784 & 26173 & 11360 & 3812 \\
\hline & Amphi_RANA & SRX1615785 & 27188 & 182 & 123 \\
\hline & Reptile_SNAKE & SRX1615783 & 1616 & 1106 & 63 \\
\hline & Reptile_TURTLE & SRX1615795 & 12609 & 0 & 0 \\
\hline \multirow[t]{6}{*}{ Saint-Jean } & Amphi_A & SRX1615135 & 23 & 1 & 0 \\
\hline & Amphi_B & SRX1615150 & 18067 & 16588 & 0 \\
\hline & Amphi_C & SRX1615133 & 24579 & 11784 & 0 \\
\hline & Amphi_RANA & SRX1615134 & 28681 & 1450 & 1194 \\
\hline & Reptile_SNAKE & SRX1615132 & 186 & 23 & 0 \\
\hline & Reptile_TURTLE & SRX1615173 & 2057 & 0 & 0 \\
\hline \multirow[t]{3}{*}{ Légaré } & Amphi_A & SRX1615837 & 6 & 0 & 0 \\
\hline & Amphi_B & SRX1615838 & 2976 & 2445 & 0 \\
\hline & Amphi_C & SRX1615835 & 11873 & 337 & 0 \\
\hline
\end{tabular}




\begin{tabular}{|c|c|c|c|c|c|}
\hline \multirow{8}{*}{ Aylmer } & Amphi_RANA & SRX1615836 & 26637 & 15831 & 15793 \\
\hline & Reptile SNAKE & SRX1615796 & 217 & 3 & 0 \\
\hline & Reptile_TURTLE & SRX1615839 & 838 & 0 & 0 \\
\hline & Amphi_A & SRX1615859 & 22 & 0 & 0 \\
\hline & Amphi_B & SRX1615860 & 34866 & 32002 & 0 \\
\hline & Amphi_C & SRX1615842 & 27412 & 10983 & 1116 \\
\hline & Amphi RANA & SRX1615857 & 33106 & 5513 & 5399 \\
\hline & Reptile_SNAKE & SRX1615840 & 939 & 440 & 0 \\
\hline \multirow{4}{*}{ Nominingue } & Reptile_TURTLE & SRX1615861 & 2504 & 0 & 0 \\
\hline & Amphi_A & SRX1615867 & 13 & 1 & 1 \\
\hline & Amphi_B & SRX1615869 & 7015 & 6459 & 0 \\
\hline & Amphi_C & SRX1615864 & 31871 & 26199 & 4908 \\
\hline \multirow{8}{*}{ Baskatong } & Amphi_RANA & SRX1615865 & 2215 & 0 & 0 \\
\hline & Reptile_SNAKE & SRX1615862 & 278 & 55 & 0 \\
\hline & Reptile_TURTLE & SRX1615871 & 23062 & 5 & 0 \\
\hline & Amphi_A & SRX1615879 & 13 & 2 & 0 \\
\hline & Amphi_B & SRX1615881 & 50131 & 46591 & 0 \\
\hline & Amphi_C & SRX1615875 & 31424 & 20588 & 2516 \\
\hline & Amphi_RANA & SRX1615877 & 23281 & 5523 & 2709 \\
\hline & Reptile_SNAKE & SRX1615873 & 3094 & 1835 & 0 \\
\hline \multirow{4}{*}{ Renne } & Reptile_TURTLE & SRX1615883 & 1611 & 1 & 0 \\
\hline & Amphi_A & SRX1613044 & 21 & 4 & 4 \\
\hline & Amphi_B & SRX1613076 & 52646 & 48930 & 105 \\
\hline & Amphi_C & SRX1613035 & 31474 & 20825 & 747 \\
\hline \multirow{8}{*}{ Yamaska } & Amphi_RANA & SRX1613037 & 33252 & 29668 & 29608 \\
\hline & Reptile_SNAKE & SRX1611550 & 1606 & 829 & 0 \\
\hline & Reptile TURTLE & SRX1613077 & 521 & 5 & 5 \\
\hline & Amphi_A & SRX1613115 & 61 & 1 & 1 \\
\hline & Amphi_B & SRX1613116 & 45912 & 39321 & 113 \\
\hline & Amphi_C & SRX1613113 & 48319 & 36367 & 3583 \\
\hline & Amphi_RANA & SRX1613114 & 36313 & 33524 & 33488 \\
\hline & Reptile_SNAKE & SRX1613111 & 1055 & 106 & 0 \\
\hline
\end{tabular}




\begin{tabular}{|c|c|c|c|c|c|}
\hline & Reptile_TURTLE & SRX1613117 & 707 & 28 & 28 \\
\hline \multirow[t]{6}{*}{ North Branch } & Amphi_A & SRX1613101 & 157 & 112 & 33 \\
\hline & Amphi_B & SRX1613102 & 58916 & 55084 & 98 \\
\hline & Amphi_C & SRX1613095 & 72483 & 61924 & 8801 \\
\hline & Amphi_RANA & SRX1613100 & 46069 & 39339 & 39163 \\
\hline & Reptile_SNAKE & SRX1613078 & 818 & 289 & 198 \\
\hline & Reptile_TURTLE & SRX1613103 & 124 & 0 & 0 \\
\hline \multirow[t]{5}{*}{ Jackson } & Amphi_A & SRX1613107 & 816 & 33 & 10 \\
\hline & Amphi_B & SRX1613108 & 105655 & 97067 & 28 \\
\hline & Amphi_RANA & SRX1613105 & 37170 & 31874 & 31677 \\
\hline & Reptile_SNAKE & SRX1613104 & 856 & 93 & 0 \\
\hline & Reptile_TURTLE & SRX1613110 & 1916 & 0 & 0 \\
\hline \multirow[t]{5}{*}{ Quilliams } & Amphi_A & SRX1613121 & 32 & 13 & 9 \\
\hline & Amphi_C & SRX1613119 & 31622 & 22996 & 2995 \\
\hline & Amphi_RANA & SRX1613120 & 63051 & 57578 & 57412 \\
\hline & Reptile_SNAKE & SRX1613118 & 860 & 621 & 95 \\
\hline & Reptile_TURTLE & SRX1613122 & 770 & 0 & 0 \\
\hline
\end{tabular}


Table S5. Environmental DNA metabarcoding results including the number of sequences for each primer within each sampled locations (i.e. lakes and rivers). Short horizontal lines depicts that no sequence have been found for this species whereas X shows that no amplification have been done for the species. Please refer to Table S1 for Latin names.

\begin{tabular}{|c|c|c|c|c|c|c|c|c|c|c|c|c|c|}
\hline \multirow[b]{2}{*}{ Primers } & \multirow[b]{2}{*}{ Common name } & \multicolumn{7}{|c|}{ Lake } & \multicolumn{5}{|c|}{ River } \\
\hline & & Aylmer & Baskatong & Joseph & Légaré & $\begin{array}{c}\text { Nomini } \\
\text { ngue }\end{array}$ & $\begin{array}{c}\text { St- } \\
\text { Jean }\end{array}$ & $\begin{array}{c}\text { à la } \\
\text { Truite }\end{array}$ & $\begin{array}{l}\text { North } \\
\text { Branch }\end{array}$ & Renne & Yamaska & Jackson & Quilliams \\
\hline \multirow{3}{*}{ 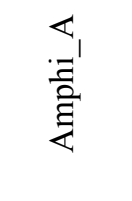 } & Snapping turtle & - & - & - & - & - & - & - & - & - & - & - & 2 \\
\hline & $\begin{array}{l}\text { Northern two-lined } \\
\text { salamander }\end{array}$ & - & - & - & - & 1 & - & - & 21 & 1 & 1 & 10 & 7 \\
\hline & Wood turtle & - & - & - & - & - & - & - & 12 & 3 & - & - & - \\
\hline \multirow{4}{*}{ 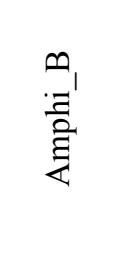 } & Spotted salamander & - & - & - & - & - & - & 421 & - & - & - & - & $\mathrm{x}$ \\
\hline & $\begin{array}{l}\text { Northern two-lined } \\
\text { salamander }\end{array}$ & - & - & 1 & - & - & - & - & 76 & 4 & 58 & 20 & $\mathrm{x}$ \\
\hline & Spring salamander & - & - & - & - & - & - & - & 22 & 43 & - & - & $\mathrm{x}$ \\
\hline & Eastern newt & - & - & - & - & - & - & - & - & 58 & 55 & 8 & $\mathrm{x}$ \\
\hline \multirow{6}{*}{$\begin{array}{l}U_{1} \\
\vec{\Xi} \\
\stackrel{\Xi}{\Xi} \\
\text { 定 }\end{array}$} & American toad & - & 1649 & 2165 & - & - & - & - & 6980 & - & 104 & $\mathrm{x}$ & 164 \\
\hline & Gray treefrog & - & - & - & - & - & - & - & 1559 & - & 974 & $\mathrm{x}$ & - \\
\hline & Spring peeper & 1116 & - & - & - & 4032 & - & - & - & - & 1541 & $\mathrm{x}$ & - \\
\hline & American bullfrog & - & 867 & 1647 & - & 876 & - & - & 250 & 701 & 396 & $\mathrm{x}$ & 2757 \\
\hline & Northern green frog & - & - & - & - & - & - & - & 12 & 46 & 568 & $\mathrm{x}$ & 74 \\
\hline & Mink frog & - & - & - & - & - & - & - & - & - & - & $\mathrm{x}$ & - \\
\hline \multirow{2}{*}{ 竞艺 } & Gray treefrog & - & - & - & - & - & - & - & 11 & - & 1 & - & - \\
\hline & Spring peeper & - & - & - & - & - & - & 1 & - & - & - & - & - \\
\hline
\end{tabular}




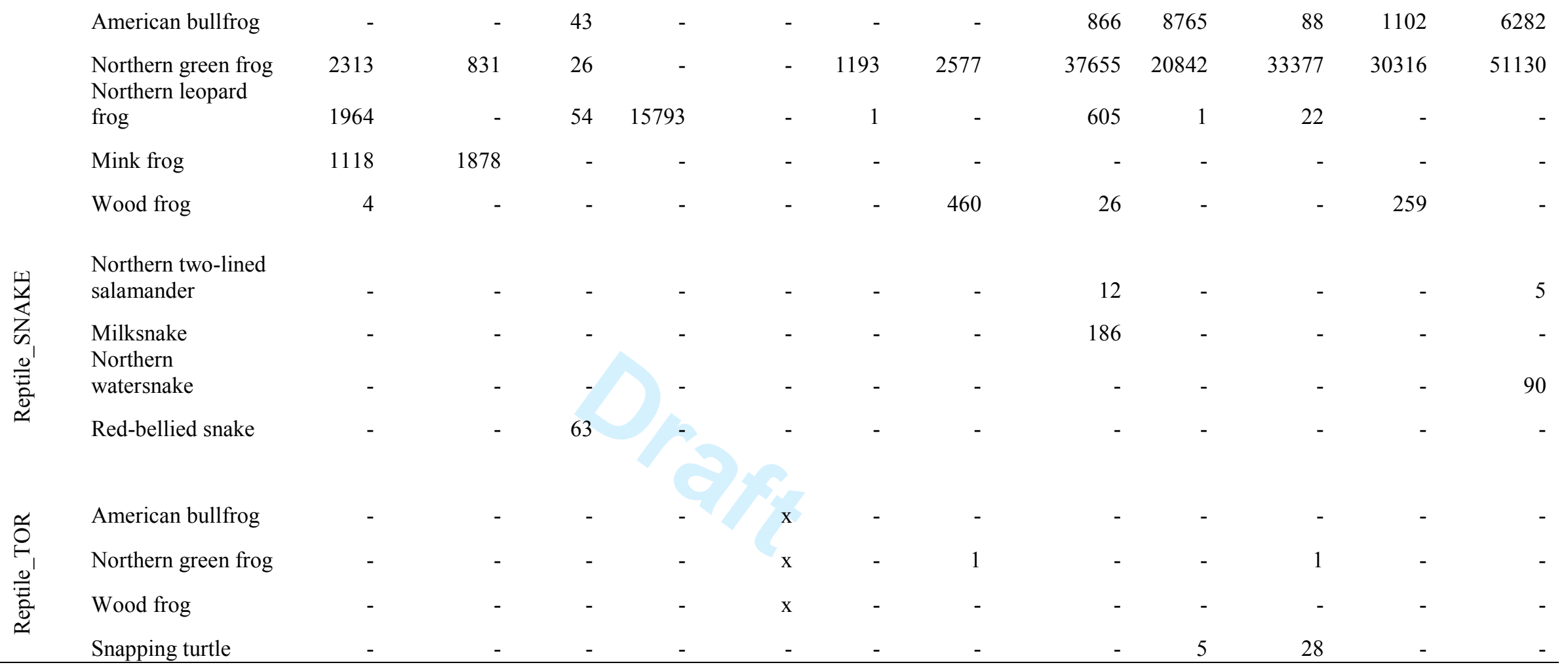


Table S6. Per base sequence quality using FastQC version v0.11.3 for the amplified regions of interest for each primer pair separately: (A) Amphi_A, (B) Amphi_B, (C) Amphi_C, (D) Amphi_RANA, (E) Reptile_Turtle, (F) Reptile_SNAKE. Please see Table 3 for the sequences and total expected length for each primer pair and Table S1 for species targeted within each of the group-species primer set.

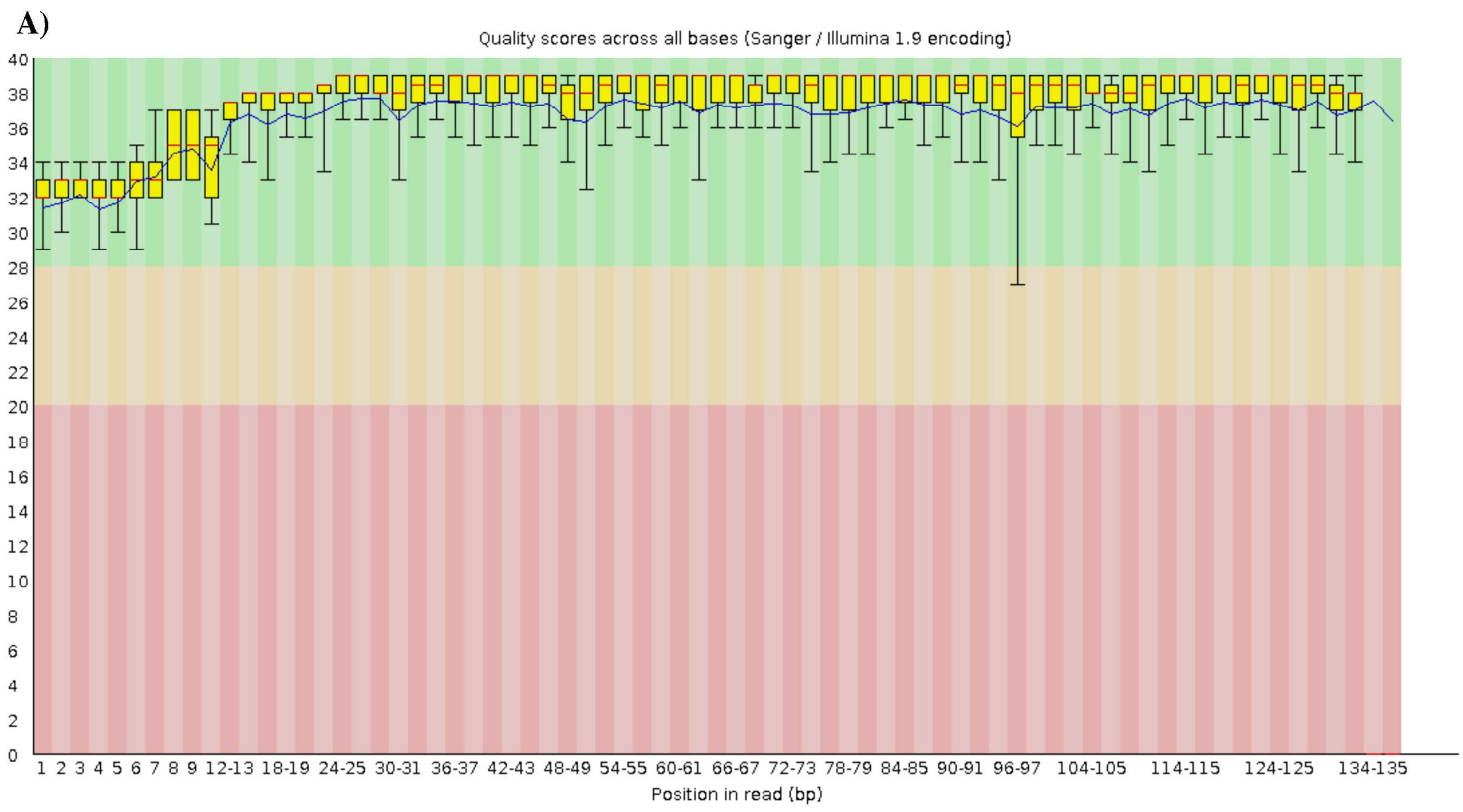


B)

Quality scores across all bases (Sanger / Ilumina 1.9 encoding)

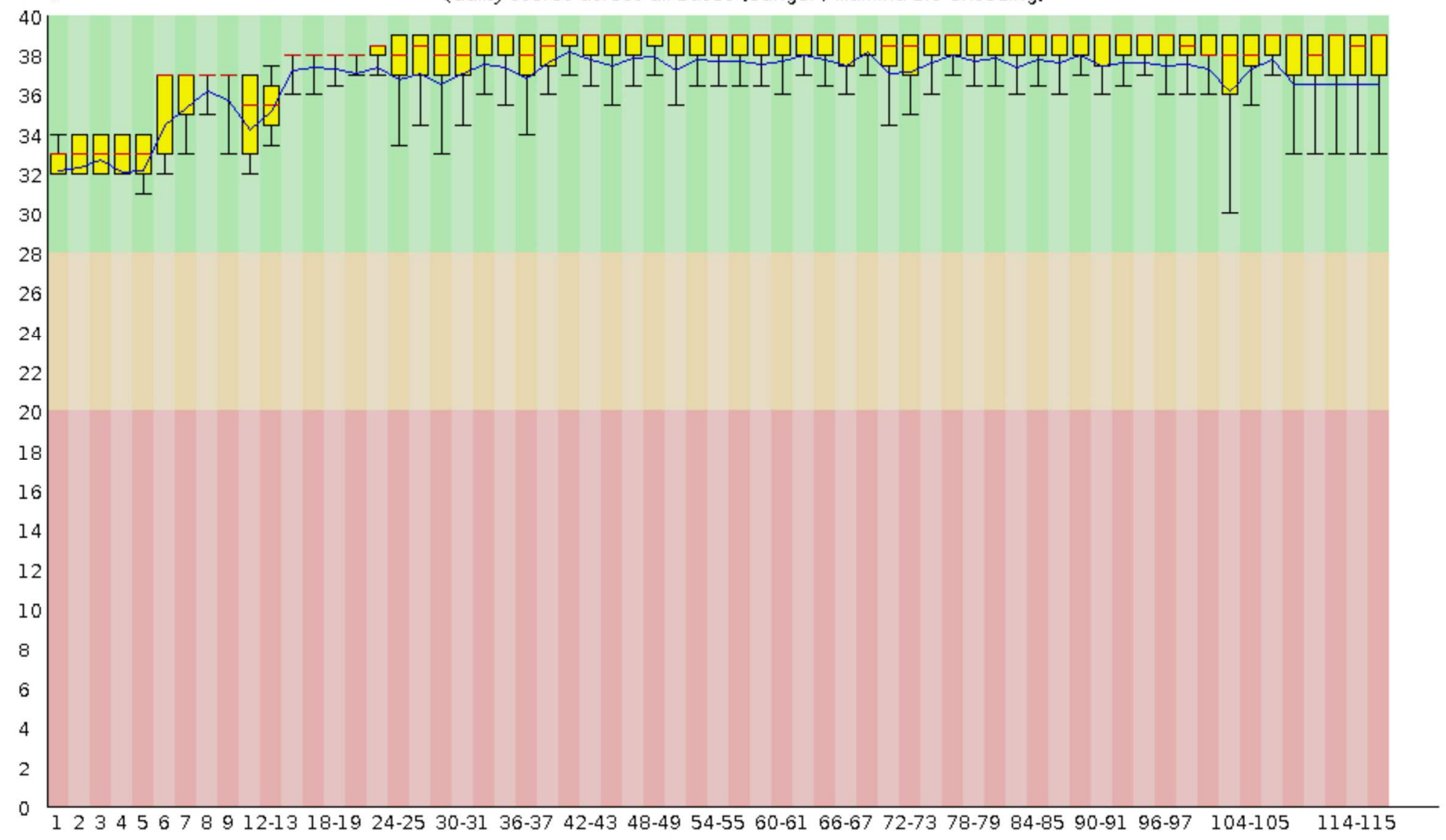
Position in read (bp) 


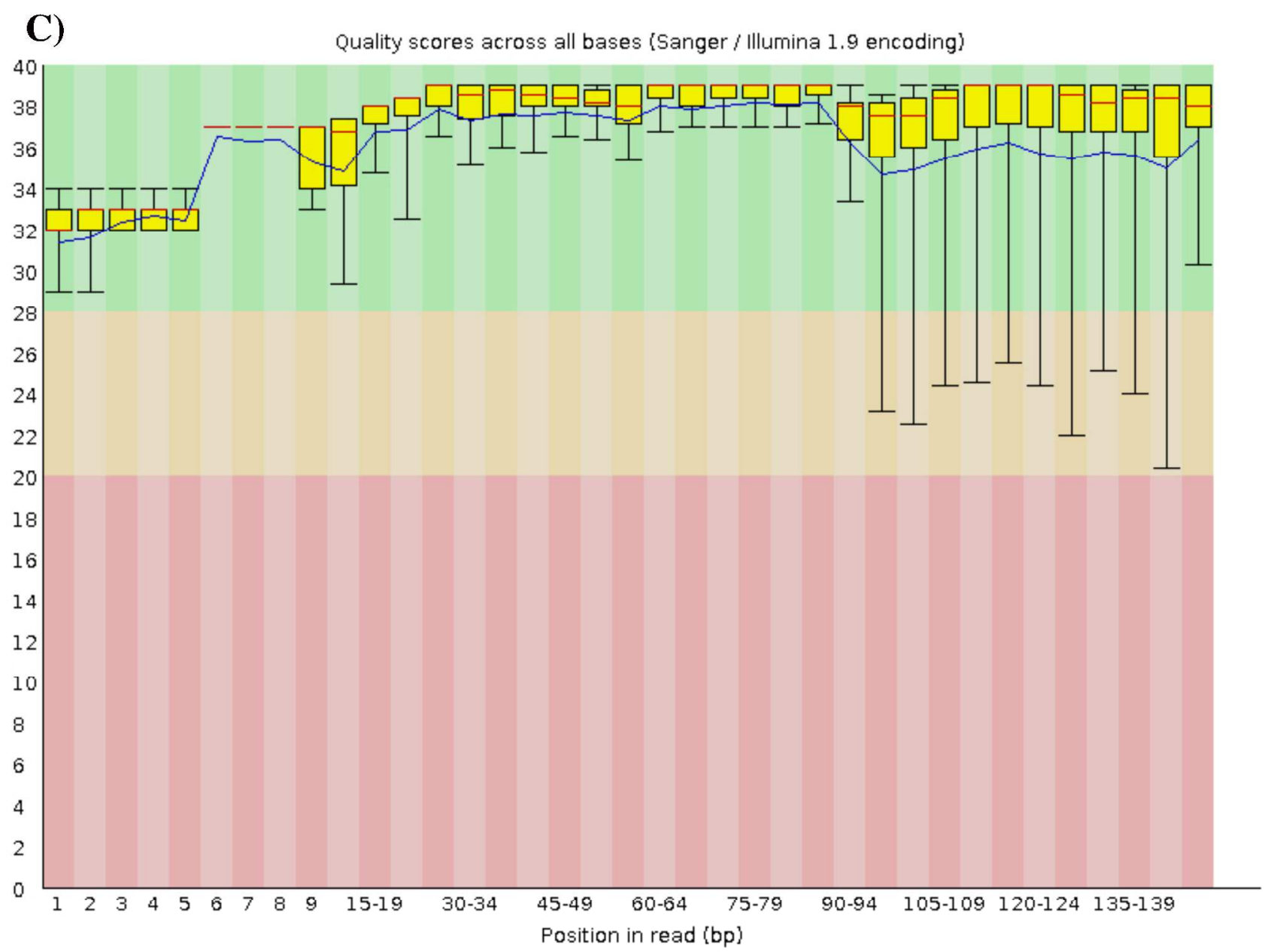




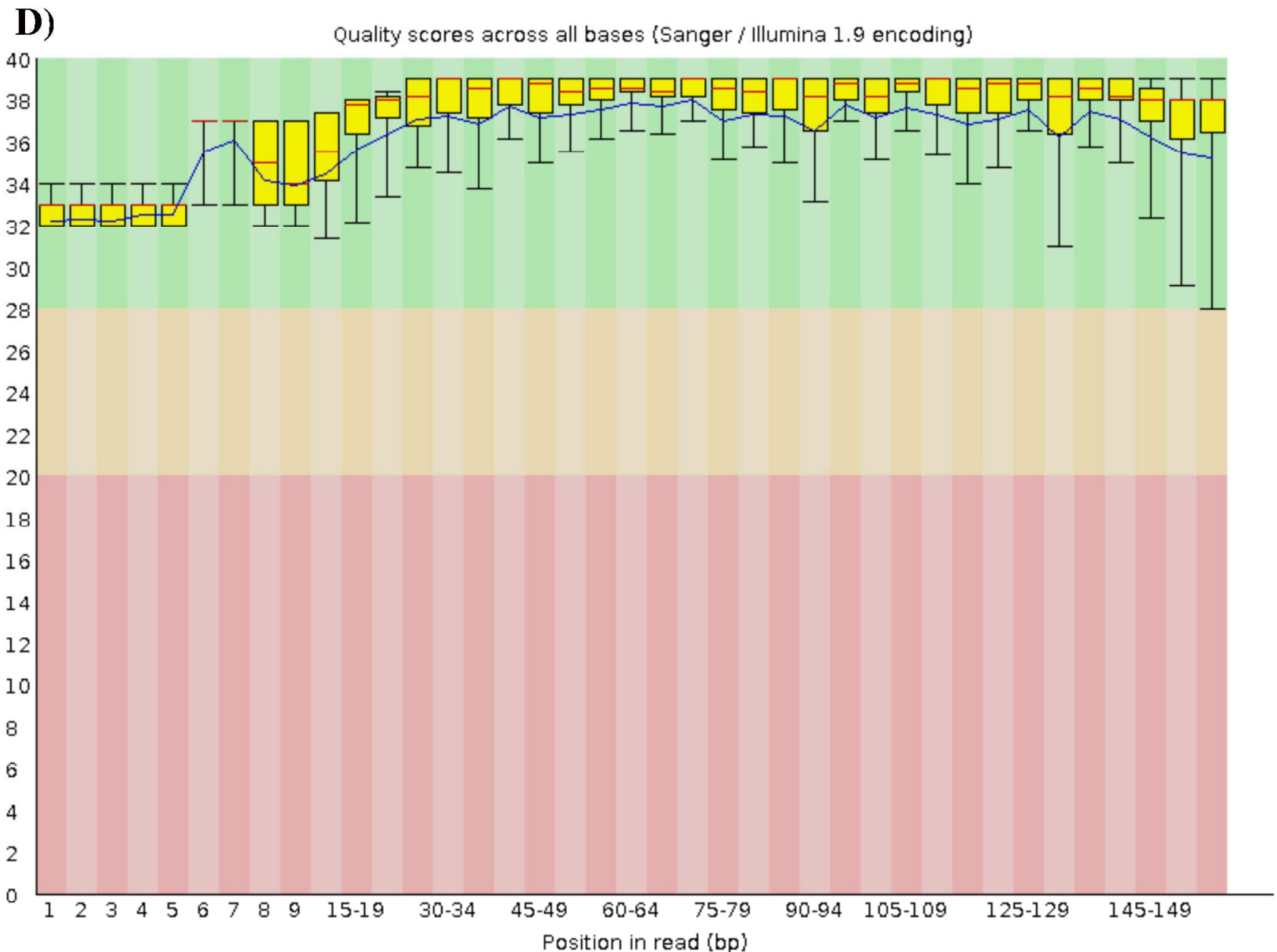




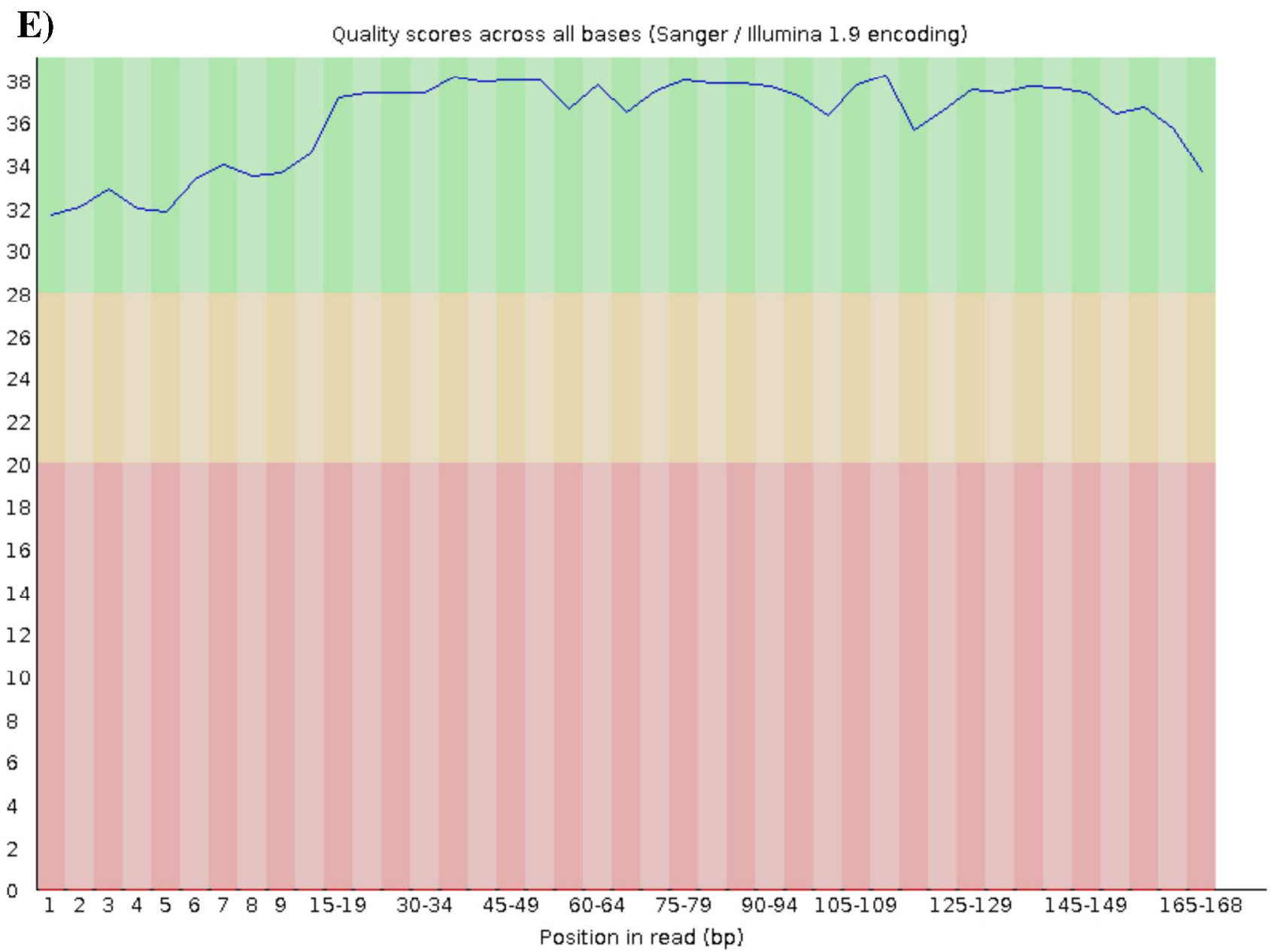


F)

Quality scores across all bases (Sanger / Ilumina 1.9 encoding)

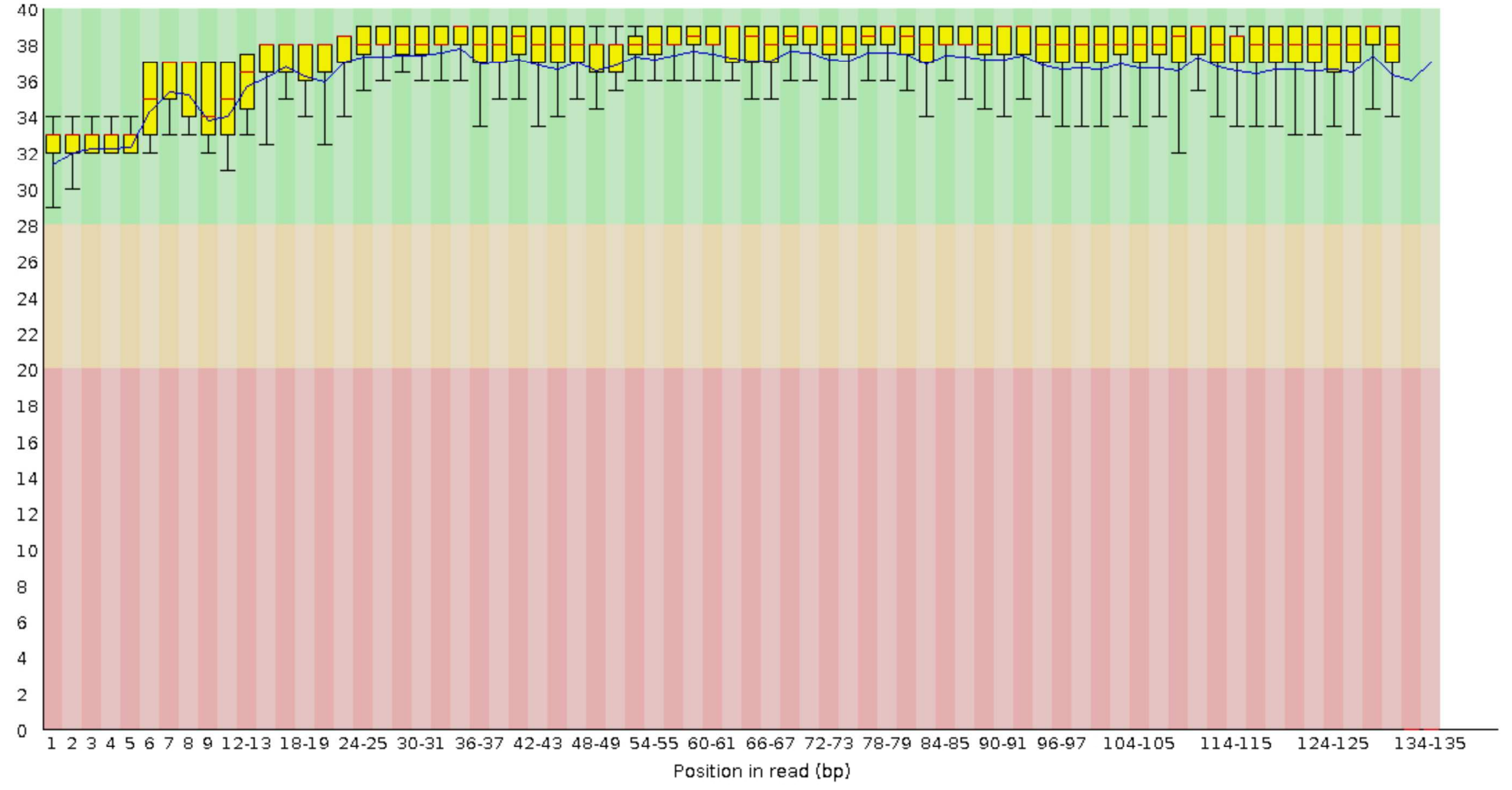

